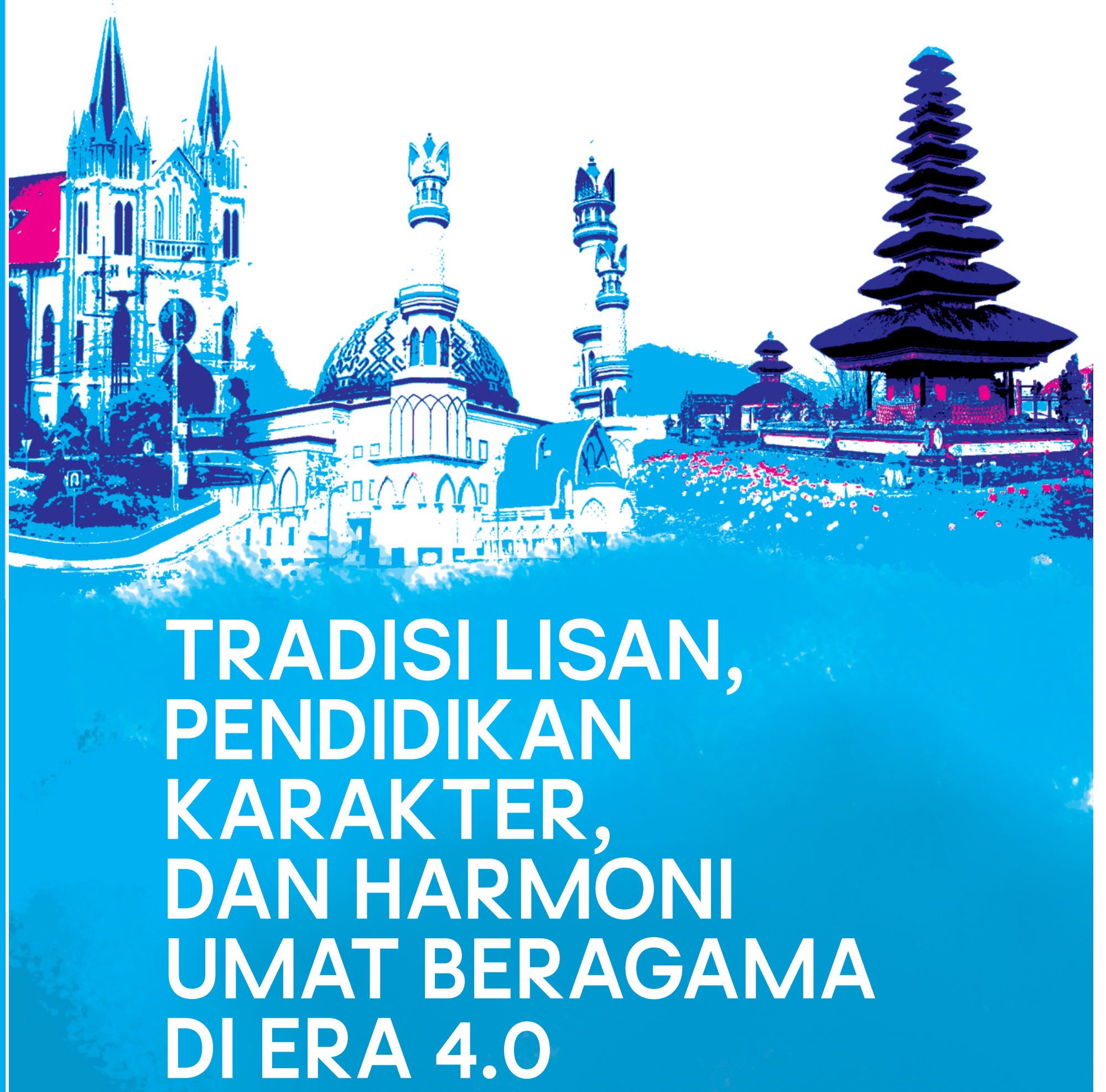

PENGalaman BALI,

LOMBOK, DAN JAWA

Editor:

Roch Aris Hidayat

Agus Iswanto 


\section{TRADISI LISAN, PENDIDIKAN KARAKTER, DAN HARMONI UMAT BERAGAMA DI ERA 4.0 PENGALAMAN BALI, LOMBOK, DAN JAWA}

Editor: Roch Aris Hidayat dan Agus Iswanto

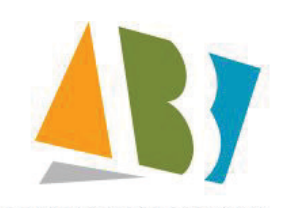

ARTI BUMI INTARAN 
Penulis: Mustolehudin, Subkhan Ridlo, Roch Aris Hidayat, Umi Masfiah, Agus Iswanto, Bisri Ruchani, Moch Lukluil Maknun, Nur Laili Noviani

Editor: Roch Aris Hidayat dan Agus Iswanto

Layout dan Desain Cover: Mohammad Azzam Ashari

Ahmad Baharuddin

Cetakan Pertama: September 2019

$16 \times 24 \mathrm{~cm}, \mathrm{vi}+352 \mathrm{hlm}$

ISBN: 978-602-5963-68-1

\section{Arti Bumi Intaran}

Jl. Mangkuyudan M.J III/216-Yogyakarta

Telp/Facs: (0274) 380228

Email: artibumiintaran@gmail.com

ANGGOTA IKAPI

Perpustakaan Nasional: Katalog Dalam Terbitan (KDT)

Hak cipta dilindungi undang-undang

Isi diluar tanggujawab percetakan 


\section{PENGANTAR EDITOR}

Buku ini tentu diterbitkan dengan sebuah misi. Misi itu adalah menunjukkan modal sosial dan kultural yang dimiliki oleh masyarakat Indonesia dalam membangun bangsanya yang harmonis. Buku ini justru hadir tepat waktu, hal itu karena akhir-akhir ini orang mulai mencari "akar" di tengah badai globalisasi dan era yang disebut dengan 4.0; sebuah era yang ditandai dengan disrupsi, ketercerabutan orang dari akar dan nilai-nilai normatif kehidupan yang kukuh.

Buku ini hadir atas inisiatif para peneliti bidang lektur, khazanah keagamaan, dan manajemen organisasi di Balai Litbang Agama Semarang. Salah satu obyek di bidang khazanah keagamaan adalah mengenai tradisi lisan (oral tradition). Buku ini adalah suatu upaya mengkontekstualisasikan beragam tradisi lisan yang ada di berbagai masyarakat yang diteliti ke dalam situasi dan kebutuhan saat ini. Hadirnya buku ini bukan merupakan suatu "langkah mundur" yang terjebak pada "romantisme" belaka karena terlalu mengunggulkan tradisi. Namun, buku ini berupaya mencari sisi postitif dari berbagai tradisi lisan yang masih hidup dan penting untuk menjadi sumber penguat pendidikan karakter, dan modal sosial-kultural dalam membangun harmoni antarumat beragama.

Ada tujuh tulisan yang masing-masing menyajikan tradisi lisan yang berbeda-beda di berbagai daerah. Tujuh tulisan tersebut diantarkan oleh satu tulisan prolog, 
dan diakhiri dengan epilog yang mencoba menawarkan bagaimana tindak lanjut dari beragam tulisan hasil penelitian tentang tradisi lisan dalam buku ini. Tidak semua tulisan adalah hasil penelitian terbaru, beberapa tulisan adalah hasil penelitian dua tahun ke belakang. Karena masih kontekstualnya pembahasan, maka tulisan tersebut tetap dimasukan dalam buku bunga rampai ini. Tulisan-tulisan menyajikan tradisi lisan dari berbagai daerah yang masuk ke dalam wilayah kerja Balai Litbang Agama Semarang: Jawa Tengah, Yogyakarta, Bali, dan Lombok. Hal yang menarik adalah ketiga wilayah tersebut memiliki titik persinggungan dalam hal kebudayaan.

Beragam tulisan tersebut disusun sedemikian rupa sehingga menampilkan urutan tulisan terbanyak, yakni mulai dari Bali hingga Jawa. Namun untuk menengahi tulisan-tulisan yang mengulas tradisi lisan di Bali dan Jawa, ditampilkan tulisan tentang tradisi lisan yang berasal dari Lombok. Semua tulisan dibiarkan seperti semula sebagaimana yang disajikan oleh para penulis. Editor hanya mengubah format penyajian agar lebih mudah dan nyaman bagi pembaca. Semua sub pembahasan utama sebisa mungkin ditandai dengan font tulisan yang besar, sedangkan sub pembahasan kedua dituliskan dengan font tulisan kecil. Hal itu dilakukan untuk mensistematisasikan logika penulisan tiap-tiap tulisan. Beberapa tulisan menggunakan sistem transliterasi dan ada yang tidak. Oleh karena itu, untuk lebih memudahkan proses penyuntingan, semua transliterasi diserahkan sepenuhnya pada format penulis. 
Terakhir, sebuah buku yang hadir di tangan pembaca adalah hasil kerja keras dan proses panjang; mulai dari penulisan, bahkan sebelumnya melalui proses penelitian yang melelahkan, proses review, penyuntingan, layout, desain sampul, hingga pemeriksaan baca, dan pendanaan. Ada banyak pihak yang terlibat dan lelah bekerja keras untuk terbitnya buku ini. Oleh karena itu, sebagai editor, dengan segala kerendahan hati kami mengucapkan terima kasih kepada pihak-pihak yang telah berkontribusi.

Selamat membaca dan mengambil hikmah!

Editor

Roch Aris Hidayat

Agus Iswanto 


\section{DAFTAR ISI}

Pengantar Editor - i

Daftar Isi - v

PROLOG:

TRADISI LISAN SEBAGAI PENGUAT IDENTITAS DAN HARMONI

Moch. Lukluil Maknun dan Umi Masfiah — 1

SENI, RELIGI, DAN TRADISI: DIALEKTIKA BUDAYA MAULUDAN BASE DI PEGAYAMAN BULELENG BALI Mustolehudin - 21

FUNGSI KESENIAN RUDAT DI KAMPUNG MUSLIM KEPAON DENPASAR BALI

Subkhan Ridlo - 65

NILAI KEARIFAN LOKAL DALAM GEGURITAN JOHARSA Roch Aris Hidayat - 99

TRADISI SORONG SERAH AJI KRAMA DI PULAU LOMBOK NUSA TENGGARA BARAT

Umi Masfiah - 137

TRADISI NGABEKTEN: ARTIKULASI HARMONI AJARAN ISLAM DAN BUDAYA JAWA DI KERATON YOGYAKARTA Agus Iswanto - 165 
TRADISI MERTI CODE DI KOTA YOGYAKARTA

Bisri Ruchani -217

PERMAINAN MENDALAM: CATATAN TENTANG SINTREN

PEKALONGAN

Moch. Lukluil Maknun - 249

EPILOG: PENDIDIKAN KARAKTER DALAM TRADISI MELALUI TEKNOLOGI UNTUK GENERASI MILENIAL

Nur Laili Noviani — 297 


\title{
PERMAINAN MENDALAM: CATATAN TENTANG SINTREN PEKALONGAN
}

\author{
Moch. Lukluil Maknun
}

\section{PENDAHULUAN}

Nancy Florida pernah mengasumsikan kedatangan Islam di wilayah pesisir utara telah menghancurkan budaya kuno luhur dan mencemari bahasa dan sastranya dengan bunyi dan rasa Arab yang asing. Meskipun demikian, di pesisir Jawa utara kemudian berkembang mitos atau folklor lisan yang mengisi kekosongan sumber sejarah setempat, yang berfungsi mirip seperti babad, yaitu sebagai sumber legitimasi identitas/komunitas. Folklor di dalam masyarakat menjadi budaya tandingan bagi karya-karya elitis yang seringkali menyingkirkan realitas massa rakyat sebagai bagian aktor sejarah. Dalam folklor masyarakat pesisir akan ditemukan sikap memaknai kekuasaan para elit pribumi atau kolonial yang dimainkan dalam pementasan massa dari rakyat, oleh rakyat, dan untuk rakyat (Setyadi, 2005: 258).

Folklor terdiri atas banyak bentuk. Suwardi Endraswara melakukan kategorisasi folklor atau tradisi lisan Jawa setidaknya ke dalam: cerita, puisi, ungkapan 
estetis, teka-teki kata, dan pertunjukan rakyat. Kategori kelima dicontohkan seperti drama Jawa, wayang, ketoprak, jemblung, dan salawatan (Endraswara, 2005: 12-13). Dalam hal ini, Sintren masuk dalam kategori pertunjukan rakyat. Lebih dari itu, Sintren juga mengandung lagu-lagu rakyat yang merupakan warisan Sintren sejak masa lalu serta menyiratkan cerita tokoh lokal Sulasih-Sulandono.

Sintren dapat dijumpai di beberapa daerah di pesisir utara Jawa. Di dalamnya terdapat unsur cerita yang menjadi benang merahnya yaitu berasal dari kisah Sulasih Sulandono. Dua tokoh yang disebut ini jika dirunut berasal dari daerah Pekalongan. Oleh karena itu, kajian difokuskan pada daerah ini.

Kajian-kajian Sintren sudah banyak yang dilakukan, di antaranya sebagai berikut. Ilyas dan Abidin dengan lokasi yang sama, Kabupaten dan Kota Pekalongan berupaya mengungkap makna spiritualitas pada penari Sintren. Pendekatan yang dilakukan adalah Interpretative Phenomenological Analysis dengan tujuan mengungkap pemaknaan partisipan terhadap dunia individu dan sosialnya. Sayangnya pembahasan Ilyas dan Abidin masih kurang mendalam karena diakui penggalian data berbasis wawancara semata. Meskipun demikian, disampaikan temuan menariknya dari dua partisipan Sintren (yang diwawancarai) yang menyatakan bahwa untuk menari Sintren, perempuan harus mengawali dengan melaksanakan perintah Allah dan menjauhi larangan-Nya, selain itu, partisipan Sintren menyatakan bahwa sebagai makhluk 
ciptaan Allah, manusia harus saling menghormati bahkan terhadap makhluk yang tidak tampak (Ilyas \& Abidin, 2016).

Aditama yang mengkaji Sintren dengan pendekatan metafisika Anton Bakker berusaha mendeskripsikan pengertian Sintren, bagian-bagiannya, mitologinya, sejarah, bentuk, dan konsepnya. Kajian yang dilakukan Aditama merupakan studi kepustakaan dengan data utama buku "Revitalisasi Kesenian Sintren" karya Dr. Atik Triratnawati, dosen Antropologi UGM. Berbagai data disarikan Aditama dari buku Atik tersebut, termasuk nilai-nilai yang terkandung dalam Sintren. Pendekatan metafisika lebih bermuara pada nilai religius yang mana redaksi yang dituliskan Aditama masih terlalu ringkas dan muncul bias. Di sana disebutkan bahwa pertunjukan Sintren merupakan 'budaya praIslam' yang masih menggunakan mantra dan mengundang roh halus. Sementara pada kalimat akhirnya dikatakan bahwa dalam ritual dan syair Sintren terdapat pengucapan bismillahbismillah untuk mengawali sebagai bukti konkrit pengakuan terhadap Tuhan, Allah SWT (Aditama, 2016). Pada bagian kajian ini akan disinggung komentar terhadap hal ini.

Haeri menulis dalam halaman blog tentang pemaknaan Sintren yang dikatakan warisan dakwah walisongo yang ramah. Dengan setting data di daerah Cirebon, dikatakan bahwa dalam pertunjukan Sintren terdapat kolaborasi antara kreasi, kekuatan intelektual, pemahaman budaya mendalam, serta penelusuran aspek religiusitas Islam yang digunakan para wali untuk berdakwah. Haeri juga 
memberikan contoh-contoh pemaknaan tanda dalam pertunjukan Sintren yang dalam beberapa kasus terlihat terlalu bebas (Haeri, 2017). Hal ini yang nantinya juga akan dikomentari dalam bagian di kajian ini.

Kajian-kajian sebelumnya sebagaimana disebutkan di atas belum ada yang mengkaji nilai keagamaan yang ada di dalamnya dengan pendekatan etnografis/antropologis. Oleh karena itu, kajian ini berusaha mengungkap hal tersebut.

\section{Deskripsi Awal Sintren}

Untuk memulai kajian Sintren, penulis perkenalkan terlebih dulu sebuah deskripisi kesenian ini. Salah satu deskripsi Sintren yang mewakili adalah deskripsi pementasan Sintren di Desa Menjangan pada 22 Desember 2003 oleh Setyadi sebagai berikut (Setyadi, 2005: 259).

Sekitar jam 9 malam di sebuah lapangan para penonton berkumpul membentuk kalangan menyerupai lingkaran. Di tengah kalangan terdapat kurungan ayam yang ditutup kain. Seorang pawang membuka acara dengan melakukan ritual dan membakar kemenyan. Selesai ritual, seorang panjak (dayang/pengiring) muncul membuka kurungan dan memastikan kepada penonton bahwa di dalam kurungan tidak ada sesuatu. Seperangkat pakaian yang terdiri dari kostum dan kaos kaki penari, kacamata hitam, sapu tangan, minyak wangi, kembang, kemenyan, dan sebuah tampah (nyiru) diletakkan di dalam kurungan kosong itu. Setelah itu seorang gadis belia yang berumur belasan tahun masuk ke dalam kurungan. Masuknya sang gadis diikuti alunan tembang waranggono dan para panjak yang diiringi seperangkat gamelan sederhana terdiri dari demung, gambang, gong, kendang, dan kempul 
Tembang yang dinyanyikan diawali dengan tembang Sulasih-Sulandono:

\section{Solasi Solandono}

Ana Menyan Ngundangi Dewa

Ana Dewa Dening Suksma

Widodari Tumuruna

Diikuti tembang lainnya.

Kinjeng-kinjeng etok, merembete nang kayu dengklok Ari kakang ojo mlerok, Sintrene isih trap entrok

Kinjeng-kinjeng putih, merembete nang godong kluwih

Ari kakang ojo noleh, Sintrene lagi trap tapih

Kinjeng-kinjeng abang, merembete nang godhong gedhang

Ari kakang ojo ngadang, Sintrene isih trap kembang

Sementara lagu pengiring dinyanyikan, gadis belia di dalam kurungan itu sedang berganti pakaian dan menghias diri. Selesai berhias dan berpakaian, si gadis yang sudah berganti kostum penari tersebut menggoyanggoyangkan kurungan sebagai tanda bahwa dia sudah siap untuk pentas. Melihat tanda itu, seorang panjak kemudian bergegas mengangkat kurungan dan meletakkannya di pinggir kalangan. Sementara tampak si gadis yang sudah berbusana itu, dengan menggunakan kacamata dan kaos kaki duduk di tengah arena dengan kedua kakinya tertekuk dan kedua tangannya terlipat di atas lutut serta wajah terbenam di antara lipatan tangan. Suara gamelan terus berbunyi mengiringi tembang "kembang mbako" sebagai pembuka tarian. 
Kembang-kembang mbako, kacamatane abang ijo Kupu tarung loro-loro, Sintrenen metu kembange ngrampyo

Seiring tembang itu, perlahan namun pasti kepala gadis Sintren terangkat, kedua tangan terbuka dan seorang panjak membantunya berdiri. Tubuh mulai bergoyang dengan tangan terayun ke kanan kiri sambil mengibas-ngibaskan sapu tangan, kepalanya melenggaklenggok gemulai. Setelah itu, sang penari mulai menari diiringi dengan lagu yang diminta oleh Sintren melalui sang Panjak. Sampai suatu saat di tengah-tengah pentas, penari tersebut tiba-tiba kejang dan jatuh di tanah (ndadi), dan oleh sang pawang gadis itu digendong keluar dan diusapusap kepalanya sambil dibacakan suatu mantra. Setelah sadar kembali penari itu masuk arena untuk menari sampai berakhirnya acara. (Setyadi, 2005: 259)

Kesenian Sintren sebagai tradisi massa rakyat Pekalongan-Batang selalu dikaitkan dengan sebuah cerita rakyat yaitu legenda Bahurekso. Definisi Sintren sesuai leaflet kesenian yang dibuat Pemerintah Kotamadya Pekalongan (Setyadi, 2005:259-260) sebagai berikut; Sintren adalah kesenian tradisional masyarakat Pekalongan dan sekitarnya. Sintren merupakan tarian yang berbau mistis/ magis yang bersumber dari cerita cinta kasih Sulasih dan Sulandono. Tersebut dalam kisah bahwa Sulandono adalah putra Ki Bahurekso yang menikahi Dewi Rantamsari. Raden Sulandono memadu kasih dengan Sulasih, seorang putri dari Desa Kalisalak, namun hubungan asmara terseut tidak mendapat restu dari Ki Bahurekso. Akhirnya Raden Sulandono pergi bertapa dan Sulasih memilih menjadi penari. Meskipun demikian, pertemuan di antara keduanya masih terus berlangsung melalui alam gaib. Pertemuan tersebut 
diatur oleh Dewi Rantamsari yang pada saat meninggal, jasadnya raib secara gaib yaitu dengan cara bahwa pada setiap acara di mana Sulasih muncul sebagai penari maka Dewi Rantamsari memasukkan roh bidadari ke tubuh Sulasih. Pada saat itu pula Raden Sulandono yang sedang bertapa dipanggil roh ibunya untuk menemui Sulasih dan terjadilah pertemuan di antara Sulasih dan Raden Sulandono. Sejak itulah setiap diadakan pertunjukan, sang penari pasti dimasuki roh bidadari oleh pawangnya, dengan catatan bahwa hal tersebut dilakukan apabila sang penari betulbetul masih dalam keadaan suci (perawan) dan diperankan oleh seorang gadis yang masih suci, dibantu oleh pawang dan diiringi gending enam orang.

\section{LINGKARAN HERMENEUTIKA DAN PEMAKNAAN SIMBOLIS}

Paradigma tafsir etnografi mengenal ungkapan 'lingkaran hermeneutika' yang dicetuskan Wilhelm Dilthey. Istilah ini merupakan penetrasi cara pikir pada anotasi pengalaman sehari-hari yang disebut sebagai nalar awam. Geertz mencontohkan, untuk menikmati pertandingan baseball seseorang perlu mengenal istilah-istilah yang digunakan, seluk beluk peralatan, pemain, dan isi lapangan. Ketika peneliti etnografi makna dan simbol mencari tahu apa dan bagaimana seorang asli (pemilik budaya) bersikap untuk mengekspresikan diri, maka muncul sebuah spiral bahwa mereka melihat dirinya sebagai persona, satu susunan, dan suatu titik dalam pola tertentu (Geertz, 2003: 87-88). 
Aris Arif Mundayat dalam pengantar buku "Pengetahuan Lokal" menyatakan bahwa, Geertz menyimpulkan bahwa posisi etnografer adalah perantara yang menyuarakan sudut pandang si pelaku. Posisi perantara ini mengesankan bahwa etnografer menjaga objektivitas ketika memahami fenomena kebudayaan, meskipun dalam praktiknya etnografer ikut berbagi pemaknaan dengan si pelaku kebudayaan (Geertz, 2003: xviii).

Clifford Geertz pernah mengungkapkan konsep semiotis kebudayaan. Ia yang mendukung konsep Max Weber dalam ungkapannya "manusia adalah seekor binatang yang bergantung pada jaringan-jaringan makna yang ditenunnya sendiri," menyatakan bahwa jaringanjaringan ini adalah kebudayaan dan analisis atasnya adalah ilmu interpretatif untuk mencari makna. Analisis ini adalah penjelasan setelah menguraikan ekspresi-ekspresi sosial pada permukaan yang penuh teka-teki. Kajian antropologi interpretatif tidaklah kemudian menjawab pertanyaan penelitian sendiri, melainkan mengumpulkan jawabanjawaban yang diberikan orang lain (objek penelitian) (Geertz, 1992b: 5, 39).

Ritus-ritus inti agama termasuk tarian seremonial adalah model-modelsimbolis. Simbol-simbolkognitif ataupun ekspresif keduanya merupakan sumber informasi yang bersifat ekstrinsik. Dengan simbol itu, kehidupan manusia dapat dipolakan. Pola-pola kebudayaan baik yang bersifat reilgius, filosofis, estetis, ilmiah, dan ideologis merupakan program-program. Semua itu menciptakan template (mistar 
lengkung) atau cetak biru untuk penataan proses-proses sosial dan psikologis. Tingkah laku manusia sangat plastis, yang dikontrol secara longgar oleh cetak biru genetis dan juga cetak biru kultural. Manusia sebagaimana hewan menciptakan model-model simbolis untuk mendefinisikan dirinya (Geertz, 1992a: 29-31). Peneliti membaca simbolsimbol itu untuk mendeskripsikan objeknya, atau mencatat informasi yang disampaikan objek dalam memaknai dirinya sendiri lewat simbol yang dia cipta.

\section{METODE}

Kajian ini adalah kajian etnografis yang berupaya menjelaskan Sintren di Pekalongan. Kajian etnografis memang berupaya menggunakan pendekatan emik (berdasar dari sisi pemahaman subjek yang diteliti) meskipun tidak bisa dipungkiri bahwa dimungkinkan terjadi tambahan penafsiran dari peneliti, atau bahkan bias. Akan tetapi, menghilangkan bias etnograf juga hampir mustahil, sehingga hanya bisa dikurangi (Kaplan \& Manners, 2002: 258).

Lokasi difokuskan di Kota dan Kabupaten Pekalongan sebagaimana yang disebutkan dalam pendahuluan karena memiliki dasar sumber cerita pembentuk Sintren, yaitu tokoh Sulasih-Sulandono. Data lapangan dikumpulkan pada akhir bulan November hingga awal Desember 2018.

Kajian ini juga merupakan kajian tradisi lisan yang metodenya dimanfaatkan dalam pengumpulan dan analisis data. Langkah-langkahnya meliputi pengumpulan data, klasifikasi, dan interpretasi. Pengumpulan data dilakukan 
dengan memperhatikan aspek-aspek etnografis meliputi wawancara mendalam, observasi langsung, serta studi dokumen dan dokumentasi pementasan Sintren. Informan yang diwawancarai terdiri dari informan kunci (tokoh masyarakat, praktisi seni, dukun Sintren, dan penari), serta informan biasa yang juga melengkapi informasi terkait. Dalam kajian etnografi, pengambilan data tidak hanya difokuskan pada aspek Sintren saja, tetapi juga aspek-aspek budaya yang melingkupinya. Adapun analisis data dilakukan dari sejak di lapangan dengan memilih dan memilah data, mengklasifikasikan, kemudian mendeskripsikannya secara etnografis (Endraswara, 2005: 207-213).

\section{HASIL DAN PEMBAHASAN}

\section{Sintren Pekalongan dan Identitas Masyarakat}

Mengkaji kearifan lokal adalah mengkaji kebudayaan masyarakat. Kebudayaan itu merupakan yang terwujud sebagai kecerdasan dan kebijakan yang dipilih komunitas untuk merespon lingkungan dan tantangan yang dihadapi dalam proses keberlangsungan hidup mereka. Sikap yang dipilih didasarkan pada pengetahuan-pengetahuan lokal yang umumnya diperoleh dari proses berkesinambungan dari generasi satu ke generasi berikutnya. Oleh karenanya, pengetahuan lokal menjadi bercorak khas. Kekhasan ini karena pengetahuan lokal diajarkan secara intens kepada masyarakat sehingga memiliki pengertian yang kurang lebih akan sama tentang suatu hal. Selanjutnya, pengertian dan pengetahuan tadi dijadikan acuan tindakan oleh komunitas sehingga tampak sebagai identitas kultural mereka (Thohir, 2011). 
Sebuah pengertian yang dijadikan acuan bertindak adalah pengertian yang diyakini masyarakat sebagai kebenaran versi mereka untuk menjelaskan dan memecahkan permasalahan yang dihadapi. Kebenaran itu bisa menyelinap di balik legenda, mitos, dan upacara yang ditradisikan. Sebagai contoh di Sunda, legenda Sangkuriang boleh dianggap fiktif, tetapi pesan untuk tidak mengawini ibu sebagai sebuah larangan atau hal tabu adalah kebenaran. Contoh lain, upacara sedekah laut pesisir selatan Jawa misalnya, di dalamnya terdapat mitos hubungan dengan Nyai Rara Kidul sehingga memunculkan rangkaian upacara ritual sebagai ekspresi penghormatan, balas jasa, dan lain sebagainya, selain juga sebagai pengikat komunitas. Pemaknaan tradisi ini dapat berfungsi sebagai piranti menjaga kebersamaan dan keharmonisan tanpa membedakan suku, etnik, dan agama (Thohir, 2011).

Kesenian Sintren Pekalongan ini dikaitkan dengan tokoh Sulasih-Sulandono. Sulandono diceritakan dalam satu versinya adalah putra dari Ki Bahurekso. Ki Bahurekso adalah putra dari Ki Ageng Cempaluk. Ki Ageng Cempaluk termasuk tangan kanan Sultan Agung Raja Mataram Islam yang menjadi raja pada $1613 \mathrm{M}$. Ki Bahurekso ini termasuk tokoh bersejarah yang sudah dikenal karena ditugasi Sultan Agung melakukan ekspansi kepada VOC pada 1628, tetapi gagal/kalah (Achmad, 2017). Selain itu, Ki Bahurekso juga dikenal dalam legenda sebagai tokoh pembuka alas roban dan menaklukkan penunggu hutan dari kalangan makhluk halus dengan melakukan topo ngalong $^{1}$ hingga satu riwayat

${ }^{1}$ Bertapa dengan meniru tidurnya kelelawar dengan bergantung di pohon dan posisi kepala di bawah. 
menyebut daerah yang dibuka disebut Pekalongan. Legenda Ki Bahurekso menjadi menarik karena diriwayatkan bahwa pimpinan makhluk halus penunggu alas roban yaitu Dewi Lanjar takluk dan menjadi isterinya. Dari sini, masyarakat mulai mengaitkan bahwa tokoh Sulandono adalah tokoh darah bangsawan karena keturunan Ki Bahurekso, bahkan mungkin juga putera dari Dewi Lanjar. Meskipun dapat ditafsiri bahwa Dewi Lanjar itu bisa jadi bukanlah makhluk halus, tetapi wanita biasa yang cantik jelita kemudian melakukan penempaan diri hingga memiliki keistimewaan (Hasyim, 2008). Bisa juga ditafsiri sebagai keturunan bangsawan Majapahit yang digelari dengan Dewi Lanjar. Lanjar bisa dimaknai sebagai batang kayu bambu yang ditancapkan di sawah tempat sulur tanaman kacang mengait, sehingga lanjar bisa menjadi simbol wanita yang tinggi. Sedangkan wanita bangsawan yang tinggi pada masa lampau dikaitkan sebagai putri bangsawan Majapahit ${ }^{2}$. Adapun versi cerita Sulasih-Sulandono dan Sintren pada bagian pembahasan akan lebih dijabarkan.

Peneliti menemukan setidaknya tiga macam bentuk Sintren yang ada di Kota dan Kabupaten Pekalongan. Jika dapat disebut, tiga macam itu adalah Sintren lama/asli/ kuno, Sintren modern, dan Sintren Islami. Masing-masing macam ini untuk lebih memudahkan penyebutan dan deskripsi dalam artikel ini akan disebut dengan Sintren grup A, grup B, dan grup C. Tiap grup merupakan perwakilan dari corak/klasifikasi Sintren yang ada di sana. Masing-

${ }^{2}$ Keterangan analisis dari Gus EA pada 26 November 2019. 
masing grup bisa diwakili oleh sebuah grup Sintren asli yang ditemui peneliti selama penelitian.

Klaim keaslian Sintren barangkali akan susah disimpulkan. Bisa saja tiap kelompok/grup/daerah menyatakan Sintren mereka yang lebih asli. Oleh karenanya, peneliti membuat pijakan awal deskripsi sebuah Sintren lama/asli dari ulasan novel tentang Sintren yang pernah ditulis oleh Dianing Widya Yudistira (Yudhistira, 2007). Dalam novel ini penulis berhasil menyajikan gambaran penampilan Sintren dan penarinya sebagai pertunjukan magis tradisional yang mengandung mistis. Berangkat dari gambaran novel ini, peneliti tertarik untuk mencari dan menemukan potret asli Sintren di lapangan, di Pekalongan.

\section{Diskusi Sejarah Sintren}

Sejarah Sintren di Pekalongan, baik Kota maupun Kabupaten, keduanya mengarah kepada sejarah tokoh Sulasih dan Sulandono. Akan tetapi, masing-masing daerah memiliki kekhasan yang dapat menguatkan klaim para pendukungnya. Kota Pekalongan memiliki latar laut utara, sehingga penokohan dan latarnya erat dengan laut. Sedangkan Kabupaten Pekalongan memiliki latar pegunungan/dataran tinggi sehingga terdapat cerita yang mendukung klaim asal usul Sintren pula.

Cerita Sintren Kabupaten Pekalongan diwakili oleh paparan Joko Heru ${ }^{3}$, Ketua DKD (Dewan Kesenian Daerah).

${ }^{3}$ Wawancara dengan Joko Heru, Ketua DKD Kab. Pekalongan, pada 27 November 2018. 
Dinyatakan bahwa cerita bermula dari tokoh Sulandono, seorang pemuda putra bangsawan Mataram yang menyamar untuk mencari cinta suci dari seorang gadis bunga desa bernama Sulasih, putri Ki Sentanu, seorang tokoh seni. Hubungan Sulasih dan Sulandono awalnya tidak direstui oleh Ki Sentanu. Namun, berkat kegigihan Sulandono, Ki Sentanu mau merestui dengan syarat jika Sulandono mampu menyerahkan Selendang sakti Tali Jiwa yang ada di hutan Suralaya. Ternyata Sulandono mampu mendapatkan selendang Tali Jiwa, hingga hubungan keduanya direstui. Setelahnya baru Sulandono membuka penyamaran jatidirinya bahwa ia bukan rakyat biasa, melainkan putra pembesar Mataram.

Dalam versi ringkas tersebut, jika tidak dicermati tidak akan ditemukan klaim Sintren sebagai ciri khas dari Kabupaten Pekalongan. Sebenarnya, jika diberikan penafsiran, di dalamnya terdapat kata kunci yang menunjukkan daerah dan sejarah yang mengarah kepada jati diri Kabupaten Pekalongan. Joko Heru telah membuat tafsiran cerita Sintren Kabupaten Pekalongan yang dinarasikan ke dalam sebuah cerita drama yang sering ditampilkan dalam adegan dan pementasan awal mula Sintren untuk dikenalkan kepada pihak luar sebagai berikut.

Di sebuah desa kecil di Kabupaten Pekalongan hidup sebuah keluarga seniman Ki Sentanu yang memiliki seorang anak gadis cantik bernama Sulasih. Ki Sentanu berharap Sulasih mau menjadi penari dalam kelompok seninya karena paras cantik Sulasih sangat mendukung sebagai seorang bintang pementasan. Namun, keinginan Ki Sentanu selalu ditolak oleh Sulasih. Hal tersebut membuat Ki Sentanu kecewa. 
Dibalik penolakan tersebut ternyata Sulasih secara diamdiam telah menjalin hubungan dengan seorang pemuda tampan bernama Sulandono. Hubungan tersebut tanpa sepengetahuan Ki Sentanu. Pertemuan mereka berdua dilakukan secara sembunyisembunyi.

Pada suatu saat hubungan keduanya dipergoki oleh Ki Sentanu dan membuat kemarahan Ki Sentanu pecah, Sulandono dihajarnya hingga babak belur. Sulasih memohon ayahnya untuk tidak menghajar Sulandono karena Sulasih sudah terlanjur sangat mencintai Sulandono. Apabila ayahnya masih terus menghajar, Sulasih berniat akan bunuh diri. Hal tersebut meluluhkan perasaan Ki Sentanu. Sulandono diperbolehkan dekat Sulasih apabila Sulandono mampu mememenuhi syarat yaitu mencari selendang Tali Jiwa yang diyakini Ki Sentanu mempunyai kekuatan magis luar biasa jika dipakai seorang penari dalam pementasan. Selendang tersebut berada di sebuah hutan rimba yang angker (bahasa lainnya adalah Sintru) yaitu hutan Sora Laya (masuk di kawasan Kec. Doro). Sulandono menyanggupi untuk mencari selendang Tali Jiwa sebagai syarat untuk mendapatkan Sulasih. Pada saat perpisahan keduanya Sulasih menyerahkan Saputangan Sekar jagat sebagai tanda kesetiaanya.

Perjalanan Sulandono ke hutan Sora Laya yang angker mendapat rintangan menghadapi Siluman. Namun, Sulandono mampu menghadapi dan mampu merebut senjata pusaka Raja Siluman yang ternyata senjata tersebut berubah menjadi selendang Tali Jiwa.

Di tempat yang berbeda sedang diadakan acara Bersih Desa. Sebagai bentuk acara pesta rakyat ditampilkanlah hiburan berupa tarian Ronggeng (sebuah tari pergaulan rakyat Kabupaten Pekalongan) dan Sulasih menjadi salah satu penarinya. Di tengah acara keramaian sedang berlangsung hadirlah Sulandono menyerahkan selendang Tali Jiwa. Untuk menguji keampuhan selendang tersebut Sulasih dijadikan obyek pengujian dengan ditutup kurungan dan tangannya ditali selendang tersebut. Keajaiban terjadi ketika kurungan dibuka ternyata Sulasih telah berganti pakaian dengan selendang Tali jiwa terkalungkan. Ketika musik dibunyikan Sulasih dapat menari lebih indah dari sebelumnya. Hal tersebut dilakukan hingga berulang kali untuk meyakinkan keampuhan selendang tersebut. Oleh karena tarian Sulasih yang kemasukan unsur magis dari selendang yang didapat dari tempat Sintru (angker) maka masyarakat menyebut tarian tersebut Sintren. 
Karena rasa bangga, Ki Sentanu akhirnya menerima Sulandono untuk dijadikan menantunya. Sulandono diperintahkan untuk memanggil orang tuanya sebagai langkah kelanjutan hubunganya dengan Sulasih. Ketika Sulandono menghadirkan orang tuanya, Ki Sentanu terkejut karena yang hadir adalah Ki Ageng Cempaluk seorang tokoh spiritual besar di wilayah Pekalongan. Kehadiran Ki Ageng Cempaluk menjelaskan bahwa Sulandono adalah anak dari Bahureksa/Joko Bahu seorang pembesar di wilayah Mataram. Ki Sentanu pun merasa malu dan salah tingkah akhirnya Sulasih dan Sulandono direstui untuk melangsungkan pernikahan. Hal tersebut disambut gembira oleh seluruh rakyat yang dilanjutkan dengan pesta rakyat besarbesaran. $^{4}$

Adapun sejarah Sintren yang di pesisir pantura Pekalongan (wilayah Kota), hingga penelitian selesai, peneliti belum menemukan rumusan yang tepat untuk dapat mewakili deskripsi ini. Umumnya para informan yang peneliti temui memberikan kisah yang sudah umum diberikan, yang merupakan kisah lain yang didapatkan dari hasil pengetahuan umum yang bisa dibaca dan dicari sendiri di buku atau di halaman web internet. Baik dari informan yang mewakili budayawan, hingga dari pelaku seni Sintren di pesisir pantai yang peneliti anggap paling kuno versinya. Bahkan pelaku seni Sintren yang sudah senior mengaku tidak terlalu mengerti sejarah Sintren, bagi mereka sejarah itu tidak lebih penting dibanding dengan cara pelestarian dan praktik seninya, dan memang demikian ciri cerita lisan. Kesan yang didapat peneliti saat menanyakan sejarah Sintren Kota Pekalongan adalah jawaban 'ketidakpastian' dari sebuah cerita lisan, dalam artian ada banyak versi, menggunakan istilah dan pengantar seperti 'konon, katanya, dan seterusnya'. Di dalam isi cerita pun juga

${ }^{4}$ Dikutip dari narasi paparan Sintren yang ditulis Joko Heru untuk diperkenalkan di beberapa agenda kesenian nasional. 
tidak memunculkan penguatan identitas seperti yang dapat dirasakan dalam versi cerita Sintren Kabupaten Pekalongan sebelumnya.

Versi cerita Sintren Kota Pekalongan yang peneliti maksud ini dapat diwakili dari paparan yang pernah dituliskan Aditama (Aditama, 2016) dalam jurnalnya meskipun sayang tidak disebutkan sumber cerita tersebut. Jika pembaca melakukan browsing di web dengan kata kunci 'Sintren pekalongan, sulandono, ki bahurekso' akan muncul banyak sekali bahan bacaan terkait ini, salah satunya semisal alamat web www.cintapekalongan.com., tetapi minim pencantuman sumber data. Meskipun demikian, titik jenuh pencarian dan pembacaan cerita rakyat Sintren ini akan dapat diwakili dari tulisan Aditama yang memberikan cerita Sintren dari kisah Sulasih-Sulandono dalam dua versi yang peneliti ringkas sebagai berikut.

Versi pertama, kisah percintaan Ki Joko Bahu (Bahurekso) dengan Rantamsari yang tidak disetujuai oleh Sultan Agung Mataram. Untuk memisahkan keduanya, Sultan Agung memerintahkan Bahurekso menyerang VOC di Batavia. Saat berpamitan, Bahurekso memberikan saputangan tanda cinta kepada Rantamsari. Beberapa waktu, terdengar kabar Bahurekso gugur di medan perang. Terdorong rasa sedih dan cinta, Rantamsari melacak jejak gugurnya Bahurekso melalui perjalanan sepanjang wilayah pantai utara dengan menyamar sebagai penari Sintren dengan nama Sulasih. Hingga akhirnya dengan bekal sapu tangan pemberian Ki Bahurekso, Rantamsari bisa bertemu kekasihnya yang ternyata masih hidup. Kegagalan Bahurekso menyerang Batavia membuatnya urung kembali ke Mataram, melainkan ia pulang ke Pekalogan bersama Dewi Rantamsari dengan maksud meneruskan pertapaan untuk menambah kesaktian agar bisa menyerang 
Batavia lain waktu. Sejak itu kedua pasangan itu hidup bersama hingga akhir hayat.

Versi kedua, kisah percintaan dengan tokoh Sulasih-Sulandono. Sulandono merupakan putra Bupati Mataram, Joko Bahu atau Bahurekso dengan Rara Rantamsari. Percintaan pasangan ini tidak direstui orang tua Sulandono. Sulandono kemudian diperintahkan ibunya bertapa dan diberikan selembar kain (sapu tangan) sebagai sarana kelak dapat bertemu dengan Sulasih setelah masa bertapanya selesai. Sulasih diperintahkan menjadi penari pada setiap acara bersih desa yang diadakan sebagai syarat bertemu Sulandono. Suatu saat di bulan purnama, diadakan bersih desa dengan penampilan pertunjukan rakyat. Sulasih menari sebagai bagian pertunjukan. Saat itu, Sulandono turun dari pertapaan membawa kain pemberian ibunya. Sulasih yang menari dimasuki kekuatan spirit Rara Rantamsari hingga mengalami trance dan saat demikian Sulandono melempar Sulasih dengan sapu tangannya hingga Sulasih pingsan. Saat trance/kesurupan ini disebut Sintren, sedangkan pelemparan sapu tangan disebut balangan. Pada akhirnya, Sulandono dengan ilmu yang dimilikinya dapat membawa kabur Sulasih dan mewujudkan perkawinan.

Saat peneliti mewawancarai ibu $\mathrm{M}$ dan pak $\mathrm{D}^{5}$ sebagai pelaku seni, mereka menceritakan kisah Sintren yang sepatah-patah dengan alur yang lebih mirip pada versi pertama. Meskipun terdapat keraguan/kekaburan dalam nama tokoh, tetapi alurnya serupa, yaitu: 1) tokoh laki-laki diutus perang oleh pemerintah/penguasa, 2) diisukan gugur, 3) tokoh perempuan menyusul dan ingin membuktikan kematian lelakinya dengan menyusur pantai utara dan menyamar sebagai penari (sambil mencari bekal perjalanan dengan menampilkan pertunjukan), hingga sampai 4) suatu

$5 \quad$ WawancaradenganibuM(pawangdanmantanpenariSintren) dan pak D (koordinator Sintren Arum Sari) pada 29 November 2018. 
ketika di pesisir yang mendekati Batavia pertunjukannya dilihat oleh tokoh laki-laki, 5) tokoh laki-laki mengenali tokoh perempuan dan akhirnya bisa kembali bersama.

Adapun versi cerita yang kedua, lebih banyak dikutip oleh para penulis, baik dalam bab buku karya (Dirhamsyah, 2014) seorang wartawan senior Pekalongan, buku katalog kesenian (Buku Kesenian Daerah Kota Pekalongan, 2003), maupun dalam tulisan di blog dan halaman web. Dirhamsyah menambah catatan keterangan kisah hidup SulasihSulandono terjadi pada abad 16. Sulasih merupakan anak petani miskin di desa Kalisalak, sedangkan Sulandono anak Raden Tumenggung Bahurekso dan Dewi Rantamsari. Pertemuan Sulasih dan Sulandono lewat perantara roh ibunya. Roh ibu (Dewi Rantamsari) merasuki Sulasih dan juga memanggil Sulandono yang bertapa.

Terlepas dari adanya berbagai versi kisah permulaan Sintren, peneliti berasumsi bahwa terdapat satu lagi versi cerita lisan yang mungkin saja tidak terungkap atau diyakini sebelumnya. Tokoh Sulasih dan Sulandono bisa jadi tidak benar-benar ada. Bisa saja tokoh yang diceritakan pada hakikatnya adalah tokoh Ki Bahurekso-Dewi Rantamsari yang menggunakan nama samaran Sulandono-Sulasih, seperti dalam versi pertama Aditama. Bahkan bisa saja nama Dewi Rantamsari juga samaran karena nama yang dikenang sejarah adalah nama Ki Bahurekso/Joko Bahu dan ayahnya yang sezaman dengan Sultan Agung Mataram. Versi pertama juga lebih dapat memberikan alasan munculnya kesenian Sintren di pesisir pantai utara dan tidak hanya ada di Pekalongan semata. 


\section{Pementasan Sintren}

Baik Sintren tradisional maupun modern terdapat unsur acara yang terdapat dalam rangkaian pementasan Sintren. Tiap daerah dan tiap pementasan dapat dimungkinkan menyajikan urutan dan penampilan yang berbeda. Akan tetapi, terdapat unsur acara yang dipastikan ada selain unsur utamanya (pemain, pawang, dan perlengkapan).

Sintren Kabupaten Pekalongan secara umum memiliki urutan penampilan sebagai berikut:

1. Pembukaan

2. Sintren, dayang pengiring, dan pawang masuk menari ke arena

3. Pembacaan mantra memohon kekuatan suguhan atraksi

4. Persiapan Sintren dibacakan mantra sampai tidak sadarkan diri dan dimasukkan dalam kurungan dengan sebelumnya tangan ditali oleh penonton

5. Pembukaan kurungan dan Sintren menari bersama dayang-dayang Sintren

6. Balangan: adalah acara Sintren dilempar selendang (selendang tali jiwa) dan jatuh tak sadarkan diri kemudian dimasukkan ke dalam kurungan untuk berganti pakaian yang kedua kalinya

7. Sintren berganti pakaian kedua lalu menari bersama dayang 
8. Temohan: di tengah tarian, dayang mengedarkan nampan untuk meminta sumbangan sukarela dari penonton

9. Sintren dimasukkan kurungan untuk berganti pakaian yang ketiga kalinya

10. Sintren menari di atas kurungan bersama dayang

11. Tarian penutup: Sintren disadarkan dan diakhiri dengan hormat kepada penonton sebagai ungkapan terima kasih atas apresiasi pada pertunjukannya ${ }^{6}$

Pada penampilan Sintren santri yang penulis saksikan di Doro Kabupaten Pekalongan, terdapat sedikit perbedaan. Acara dimulai dengan penataan alat (gamelan, kurungan, dan lain sebagainya), lalu membakar dupa/kemenyan. Setelah itu baru pembukaan dengan diawali pembacaan hadrah dan tawassul, salawat, dan syahadat. Dilanjutkan dengan tembang pembuka yang bernuansa Islami: "Ya Lal Wathan" (mars NU), Turi Putih, dan salawat Jawa. Setelah itu rombongan penari masuk arena, penari diikat, dimasukkan kurungan, hingga keluar dan menari. Ada acara balangan beberapa kali dengan selendang, lalu Sintren sempat masuk kurungan lagi dan ganti baju kedua. Menurut Gus $\mathrm{E}^{7}$ selaku pengasuh Sintren santri, dalam pertunjukkannya, bisa saja diikuti dengan acara temohan yang dilakukan oleh para pengiring (bukan penari Sintrennya). Hanya saja dalam pertunjukan yang penulis saksikan, yang dilakukan dalam

${ }^{6}$ Dikutip dari narasi deskripsi Sintren Kabupaten Pekalongan tulisan Joko Heru.

${ }^{7}$ Hasil wawancara pada saat penampilan Sintren santri menyambut klub motor oleh Lesbumi NU Kabupaten Pekalongan, 26 November 2018. 
tempo yang singkat hanya kurang lebih satu jam, adegan temohan tidak dilakukan.

Adapun grup Sintren tradisional yang diwakili oleh grup AS Panjang Baru Kota Pekalongan sempat pula peneliti saksikan sekilas pada acara bersih desa di daerah pesisir pantai daerah pasar ikan (TPI). Acara Sintren saat itu hanya sebagai pembuka acara bersih desa yang menggelar wayang kulit, sehingga Sintren hanya ditampilkan kurang dari satu jam. Pada saat itu, grup penari Sintren tidak membawa peralatan gamelan, hanya peralatan rias dan baju, kurungan, serta perlengkapan perdupaan dan bunga. Sedangkan musik pengiring bergabung dengan iringan gamelan wayang. Ibu $\mathrm{M}^{8}$ selaku pengasuh dan pimpinan grup menyatakan bahwa pertunjukan Sintren AS bisa dipesan paket pertunjukkannya sesuai pesanan dan harga. Untuk penampilan malam itu, dibuat dengan biaya minimal karena hanya sebagai acara pembuka wayang. Dalam penampilan hanya disajikan beberapa adegan dan lagu (3-5) lagu yang hanya sebagai contoh dan perwakilan saja, termasuk agenda temohan juga tidak dilakukan karena sudah paket pesanan dan di-booking. Sedangkan pada penampilan yang komplit, durasinya bisa lebih lama, setidaknya 2-3 jam, bahkan bisa mulai setelah magrib hingga menjelang tengah malam.

\section{Komodifikasi Sintren Sebagai Tuntutan Zaman dan Ekonomi}

Jika dilakukan pencarian video Sintren di internet, hampir dipastikan akan ditampilkan Sintren yang sudah

${ }^{8}$ Hasil wawancara pada saat penampilan Sintren AS Panjang Baru di TPI Pekalongan, 25 November 2018. 
dimodifikasi dari konsep Sintren awal. Sintren yang mudah dijumpai adalah Sintren pengembangan dengan menampilkan pembaruan dalam hal busana, musik, tarian, dan lain sebagaianya. Hal yang masih tetap ada sebagai syarat barangkali hanya pada properti kurungan ayam yang itupun juga sudah dimodifikasi sesuai kebutuhan.

Ada tiga informan yang penulis jumpai dengan perwakilan grup seni Sintren yang diikuti/dikelola. Tiga informan ini kebetulan berada di wilayah Kabupaten Pekalongan yang dapat memberikan gambaran adanya modifikasi kesenian Sintren.

Saat berdialog kepada pak $\mathrm{C}^{9}$, ketua grup Sintren $\mathrm{BP}$, peneliti merasakan seperti sedang berdialog dengan pimpinan sulap yang menceritakan dan menunjukkan trik-trik pertunjukan yang biasa dipentaskan. Bentuk kurungan misalnya, untuk menggantikan kurungan ayam yang dulunya dari anyaman bambu, sekarang sudah dibuat dari kawat besi yang dibuat dengan las. Bentuknya tidak lagi mengerucut, tetapi seperti tabung yang bagian atasnya datar. Diameter kurungan besi ini kurang lebih 1 meter, dengan tinggi 70-80 cm. Kurungan dibuat dari besi seperti ini dikarenakan kurungan digunakan untuk melakukan atraksi, berjoget di atas, yang bahkan bisa untuk dinaiki dua atau tiga orang penari. Kadangkala kurungan ini juga bisa untuk dimasuki dua penari sekaligus sebelum penari bertransformasi menjadi penari Sintren.

Kostum yang digunakan penari grup BP juga sudah mengalami transformasi. Jika Sintren lama menggunakan

${ }^{9}$ Hasil wawancara dengan Pak C, ketua Grup Sintren Bunga Pantura Kabupaten Pekalongan, 29 November 2018. 
pakaian mirip penari remo (Jawa Timur) seperti yang masih dipertahankan oleh grup Sintren AS Panjang Baru, maka yang dikembangkan berikutnya adalah dengan berpakaian kain dan kebaya. Properti yang ditetapkan dalam pakaian Sintren adalah kacamata hitam.

Tidak hanya penari Sintren yang menggunakan kostum khusus, para pengiring pun pada grup Sintren lama (grup AS) hampir dipastikan dalam pertunjukannya menggunakan pakaian kebaya dan kain. Sedangkan dalam grup Sintren modern seperti grup BP, hanya penari Sintrenlah yang berpakaian khusus, sementara pengiring lainnya berpakaian bebas. Bahkan para penari latar yang mengiringi penari Sintren berpakaian lebih bebas dan cenderung seksi. Beda penari pengiring dengan biduan adalah pemakaian make up dan pakaian yang lebih glamor.

Pada grup Sintren santri, terjadi perpaduan pakaian, penari menggunakan kain dan kebaya disertai jilbab, para pengiring menggunakan kain batik sebagai identitas kedaerahan. Menurut pengasuh ${ }^{10}$, esensi keindahan penampilan Sintren tidak melulu pada pakaian bahkan keseksian penari, tetapi pada kemampuan penyajian penari dan kolaborasinya dengan para musik. Modifikasi pakaian ini lazim dilakukan, terutama pada penampilan Sintren santri. Jika dulu diasumsikan harga kain mahal, sehingga pelaku seni berpakaian secukupnya, maka sekarang untuk berpakaian tertutup yang sesuai syar'i sangat mudah dan bisa murah.

${ }^{10}$ Hasil wawancara dengan Gus E, pada 26 November 2019 


\section{Gambar. 1 Sintren AS Panjang Baru Kota Pekalongan}

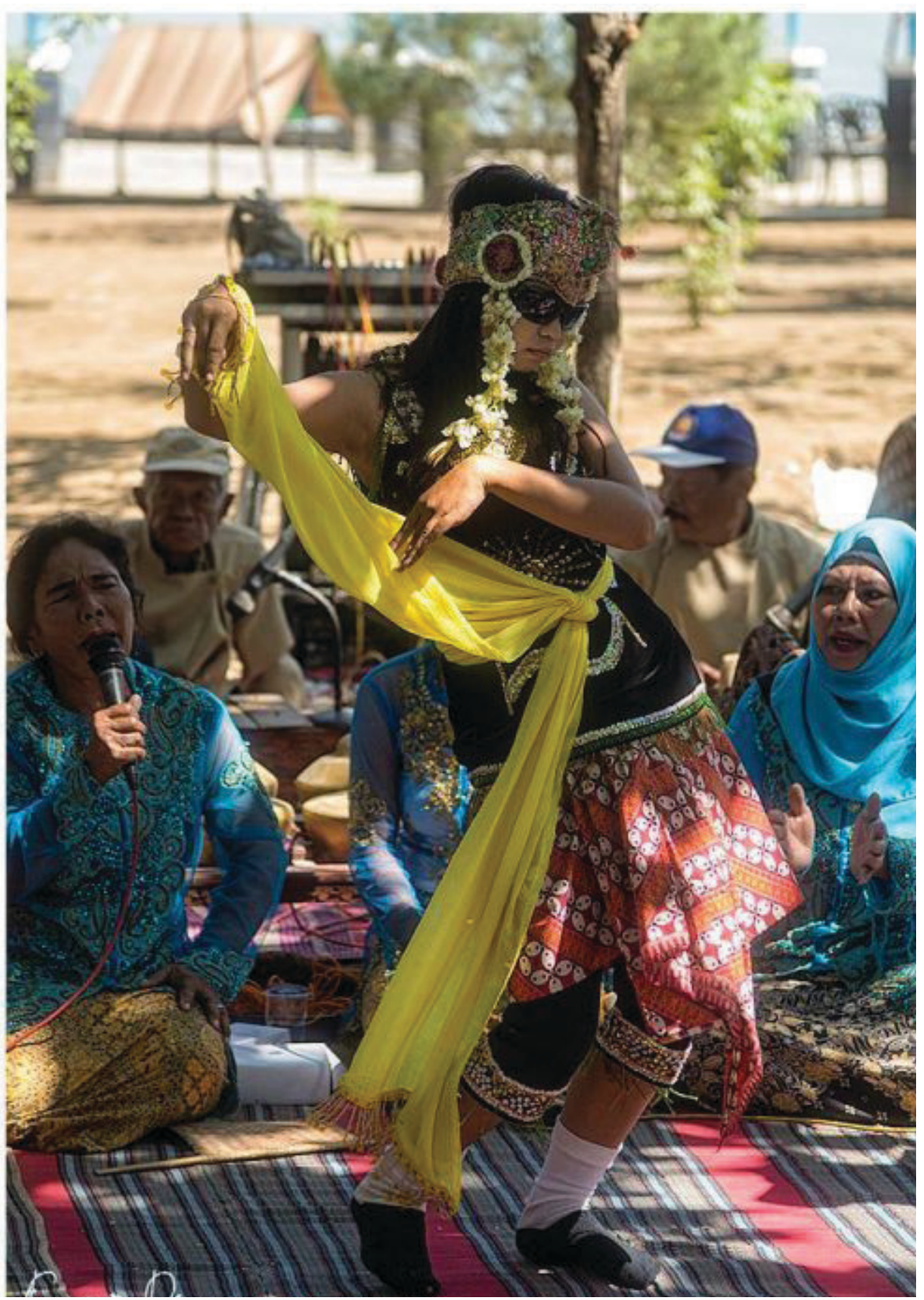

Sumber: Dokumentasi grup Sintren AS Kota Pekalongan, web: www. cintapekalongan.com 


\section{Gambar. 2 Sintren BP Sragi Kab. Pekalongan}

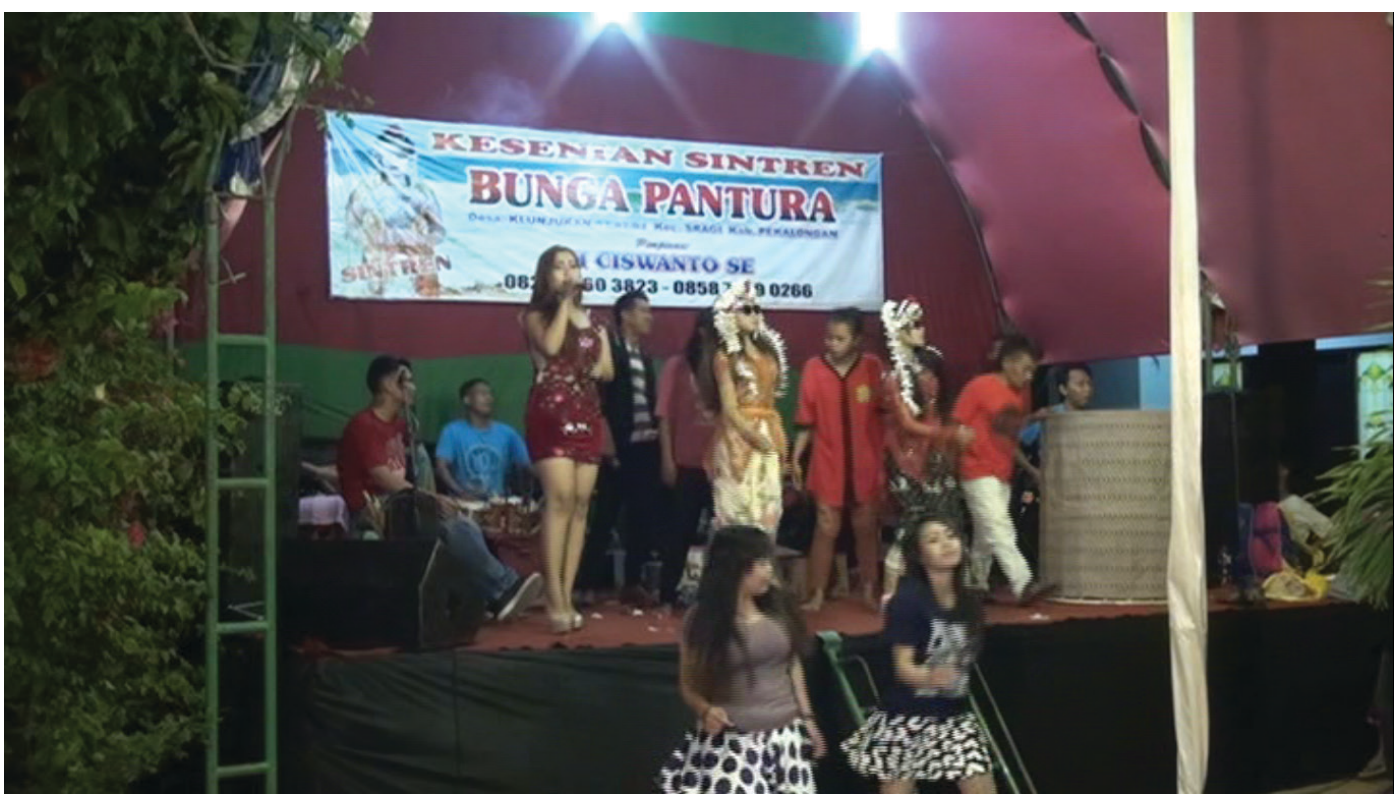

Sumber: Diolah dari VCD pertunjukan Sintren BP

\section{Gambar. 3 Sintren Santri Kab. Pekalongan}

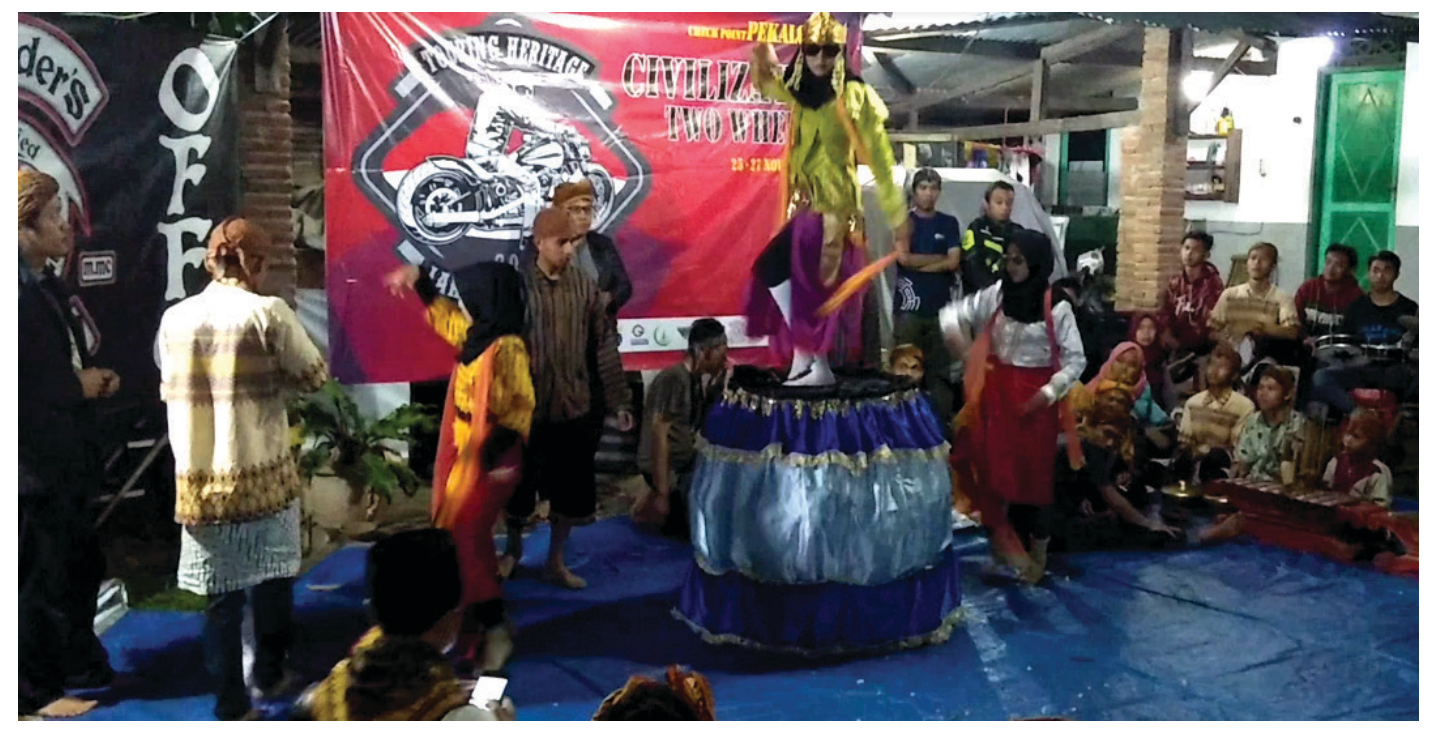

Sumber: Dokumentasi peneliti saat pertunjukan Sintren santri di Kabupaten Pekalongan

Joko Heru selaku ketua Dewan Kesenian Daerah (DKD) Kabupaten Pekalongan memberikan pembeda pada 
pertunjukan Sintren Kabupaten Pekalongan. Beberapa pembeda yang diklaim sebagai keunikan tersebut adalah sebagai berikut. 1) Pertunjukan dapat dilakukan dalam waktu yang relatif singkat yaitu sekitar 15 menit dalam sekali pertunjukan. 2) Setiap ganti pakaian hanya membutuhkan waktu 2 menit (120 detik). 3) Penari Sintren dapat diikat oleh penonton secara bebas (bukan pawang) dan ketika keluar dari kurungan masih dalam keadaan terikat. 4) Penari Sintren dapat berganti pakaian sebanyak tiga kali dalam busana berbeda. 5) Penari Sintren tidak harus perawan, wanita yang sudah mempunyai anak pun bisa menjadi penari Sintren. 6) Sintren kabupaten Pekalongan dapat menari di atas kurungan yang dulunya tidak pernah dilakukan Sintren-Sintren lainya. ${ }^{11}$

Joko Heru juga menambahkan bahwa DKD dan Lesbumi terus berkreasi untuk mengembangkan keterampilan dan kemampuan para pelaku seni yang ada di Kabupaten Pekalongan. Semisal, kemampuan berganti pakaian dan melepas ikatan dalam waktu cepat masih senantiasa dilatih untuk mencari semacam rekor baru. Di antara kunci keberhasilan hal itu selain pada intensitas latihan juga pada pemilihan bahan (kain dan tali) tertentu.

Pemertahanan kesenian Sintren di Pekalongan mengalami perjuangan pasang surut, jika tidak mau disebut berat. Grup BP asuhan bapak C misalnya, mengaku untuk saat ini minat masyarakat untuk mengundang grup Sintrennya sudah sangat berkurang dibanding dulu masa

${ }^{11}$ Dikutip dari narasi Sintren Kabupaten Pekalongan oleh Joko Heru. 
kejayaannya. Untuk saat ini, masyarakat konsumen Sintren lebih banyak menikmati hiburan Sintren sebagai penari iringan dangdut. Seni mistis yang awalnya merupakan daya tarik sekarang menjadi bergeser kepada seni yang lebih vulgar tak ubahnya minat penonton terhadap pertunjukan dangdut koplo.

Bapak $\mathrm{C}^{12}$ menyatakan bahwa tidak bisa dinafikan peran para penonton dari kaum muda sangat menentukan keberhasilan finansial pertunjukan. Grup Sintren terdiri dari banyak personel, dan sudah lazim bahwa ongkos pengundang yang dipatok memang tidak mahal. Sehingga jika dipotong untuk biaya operasional, para personil grup bisa jadi hanya mengantongi uang bensin saja antara (50100 ribu) dalam sekali pertunjukan. Oleh karena itu, peran para penonton yang menyawer sangat dinanti.

Di sisi lain, para penyawer mengharapkan hiburan vulgar, tidak lagi sebagai penikmat seni yang murni. Dalam posisi seperti ini, grup Sintren terpaksa mengikuti arus pesanan, dengan mengalahkan idealisme seni. Hal ini terlebih agar grup Sintrennya tetap hidup. Menghadapi tantangan seperti ini, strategi bapak $\mathrm{C}$ adalah menggandeng para biduan dangdut, dua atau tiga orang untuk ikut manggung bersama grupnya saat pertunjukan Sintren. Tentu saja hal ini untuk lebih menarik para penonton dan para penyawer. Meskipun dengan menyewa para biduan, honor yang dibagi akan semakin berkurang karena jatah para biduan paling tinggi. Katakan jika para personel mendapat 50 - 100 ribu,

${ }^{12}$ Hasil wawancara dengan Bapak C, pimpinan grup Sintren BP Kab. Pekalongan pada 29 November 2018. 
maka setidaknya para biduan mendapatkan bagian 500 ribu per orang. Grup Sintren adalah penjual, dan para penyawer adalah pembeli. Penjual mau tidak mau akan mengikuti permintaan pembeli jika ingin dagangannya dibeli.

Pak C sebagai ketua grup Sintren BP juga merangkap sebagai 'manajer'. Ia melatih, mengatur, dan juga membiayai gerak grup Sintren. Rumahnya dijadikan tempat berkumpul dan latihan para pemain, dan selalu terbuka. Ia menjadi bapak bagi para pemain Sintren dan peserta grup. Tidak semua pertunjukan Sintren bisa mendatangkan untung. Kadangkala pengeluarannya untuk biaya operasional (sewa alat, kendaraan, dan honor) lebih besar daripada pemasukannya. Oleh karena itu, pak C memiliki strategi keuangan dengan memberikan patokan harga untuk biaya operasionalnya, dan pada saat penghasilan pertunjukkannya lebih besar, maka sisanya menjadi tabungan grup. Di sini, grup BP dengan tuntutan ekonomi menghidupi sendiri biaya hidupnya.

Tidak jauh berbeda dengan grup BP, grup Sintren AS juga berjuang untuk menghidupi sendiri keberlangsungan grupnya. Kiranya demikian pula nasib grup dan pemain/ penari Sintren di semua daerah Pekalongan. Untuk masa sekarang, bermain Sintren tidak lagi menjadi harapan pokok untuk dapat mencukupi kebutuhan hidup, diperlukan pekerjaan lainnya untuk memenuhi nafkah. Sintren adalah kesenian dengan biaya operasional yang murah, berbeda dengan kesenian wayang atau dangdut. 
Berbeda dengan grup BP dan AS, grup Sintren santri asuhan Gus E lebih tersokong kehidupannya. Grup Sintren santri diayomi oleh Lesbumi di bawah lembaga NU. Berbagai peralatan dan biaya operasional juga dilakukan dengan swadaya, seperti perlengkapan dan bahkan seragam yang dibiayai dari iuran para pemain. Meskipun demikian, keberadaan grup Sintren santri memiliki dukungan moril yang kuat dari lembaga.

\section{Lesbumi dan Pemaknaan Simbolis Islam pada Sintren}

Lesbumi (Lembaga Seniman Budayawan Muslimin Indonesia) adalah lembaga seni-budaya yang diusung NU pada tahun 1950-1960-an. Pada masa pemerintahan Soeharto lembaga ini sempat stagnan, kemudian digeliatkan kembali pada Muktamar NU 1999 dan 2004. Lesbumi merupakan muara dari berbagai kegiatan seni budaya yang sebelumnya telah dilakukan oleh kalangan Nahdliyyin. Di kalangan orang-orang Islam telah dilakukan kegiatankegiatan seni budaya yang sesuai dengan tradisi, kebiasaan dan ajaran-ajaran Islam, meskipun seringkali kegiatankegiatan seni budaya itu dilakukan tanpa kesadaran. Semisal dari pembacaan kitab Barzanji dan Burdah telah melahirkan berbagai varian kemasan penampilan seni Islami yang kreatif dari salawatan, rebana, kasidah, samrah, dan lain sebagaianya. Menurut ketua, geliat Lesbumi penting digalakkan untuk menengahi fenomena sepi dan keringnya agama Islam dari sentuhan seni budaya sehingga memunculkan wajah sangar tanpa kelenturan. Agama sedang 
terjebak dalam ritualisme, simbolisme, dan formalisme. Oleh karenanya, Lesbumi merasa perlu mengaktifkan kembali perannya untuk memfasilitasi kesenian dan menumbuhkan kreatifitas masyarakat. Program utamanya adalah melakukan dokumentasi kesenian masyarakat terutama yang langka dan hampir hilang (Mansoer, 2007). Penggalian kearifan lokal dan dakwah multikulturalisme yang terlacak dalam kesenian rakyat akan sangat berguna mengungkap identitas bangsa dan Islam nusantara yang lemah lembut (Purwadi, 2011).

Peran dan posisi Lesbumi dalam deskripsi tersebut menjadi patokan utama alasan Lesbumi Pekalongan mengayomi seni, termasuk Sintren. Lesbumi merasa perlu mengayomi dan menggandeng Sintren untuk bisa diterima oleh masyarakat saat ini, terutama di kalangan Muslim sendiri. Gencarnya arus Islamisasi yang formalistik dengan jargon pemurnian agama dari bidah dan syirik menyasar pula pada kesenian Sintren. Betapa Sintren juga dianggap sebagai kesenian yang penuh nuansa tersebut. Padahal jika mau lebih sabar, Sintren sudah ada sejak masa para pendakwah Islam Indonesia (Jawa) sebelumnya. Tentu terdapat berbagai alasan dan pemaknaan yang menyebabkan kesenian ini dipertahankan/dibolehkan meskipun sekarang dituduh dan terkesan berbau syirik. Langkah bijak dalam melihat fenomena kesenian Sintren ini adalah menggunakan kacamata sufi atau kacamata ajaran wali masa lalu.

Simuh, salah satu pakar Sufisme Jawa, pernah menggunakanistilah dakwahkompromis dan nonkompromis. Istilah nonkompromis untuk dakwah yang relatif kaku, 
hitam-putih, dengan nuansa fikih kental, yang sekarang dekat dengan istilah formalistik. Sementara para wali dulu menggunakan pendekatan kompromis bernuansa tasawuf dalam penyebaran agama (Simuh, 2016; Nashichuddin, 2006). Dakwah yang kompromis akan dapat merangkul masyarakat Jawa yang pada masa itu sangat kental dengan aliran mistis dan kejawennya yang merupakan warisan dari generasi ke generasi (Kholil, 2007).

Beberapa pemaknaan sufistik Sintren penulis dapatkan utamanya dari pemaparan pengasuh Sintren santri, Gus EA ${ }^{13}$ Pekalongan juga para seniman di sana.

Sintren mulai punah terlebih sejak terjadi formalisme Islam, yaitu dianggap bermuatan syirik. Tuduhan ini misalnya karena dianggap di dalam Sintren melibatkan setan atau roh halus yang menyebabkan penari Sintren kerasukan. Jika pada konsep Sintren sebelumnya yang disambat (dipanggil atau dimintai tolong) adalah roh bidadari ${ }^{14}$, dalam Sintren santri ditegaskan bahwa yang disambat tak lain adalah nabi Muhammad juga. Hal ini diperkuat dengan adanya prosesi hadrah (mengirim fatihah kepada nabi Muhammad dan para leluhur) sebelum memulai acara.

Sintren jika dikaji lebih dalam sangat bernuansa Islam yang damai (salam). Pemahaman kebalikannya, jika suatu

\footnotetext{
${ }^{13}$ Wawancara dengan Gus EA pengasuh Sintren santri Kab. Pekalongan pada 25-26 November 2019

${ }^{14}$ Pak C ketua grup Sintren BP Sragi menyatakan dia dari kalangan awam berpendapat bahwa diyakini atau tidak, memang seringkali penari Sintren dapat dirasuki ruh, dan yang dipanggil adalah ruh bidadari (bisa disebut malaikat). Dia selaku orang awam pun menolak jika dituduh berlaku syirik, karena jikapun dianggap memanggil ruh, ruh yang dipanggil adalah ruh yang baik, bukan setan.
} 
kegiatan/kesenian/pertunjukan yang di dalamnya terdapat salam (kedamaian), maka kemungkinan besar adalah dari Islam juga. Anggaplah Sintren sebagai salah satu kesenian untuk media dakwah mengumpulkan masa warisan para wali, maka dapat ditangkap bahwa para wali mengajarkan tatacara berdakwah yang lembut, tidak pernah memaksa, lebih-lebih berlaku keras. Metode dakwah demikian terbukti mampu diterima lebih baik oleh masyarakat Indonesia pada masa lampau yang dapat dianggap lebih abangan atau masih bernuansa animisme. Para wali yang mengejawantahkan metode dakwah nabi yang halus dapat menarik masa secara efektif. Hal itu misalnya dilakukan dengan dakwah secara perbuatan, mendatangi penduduk di rumah, di pasar, di sawah, dan lain sebagainya, termasuk dengan model kesenian seperti wayang dan gamelan (Sofwan, Wasit, \& Mundiri, 2004). Dakwah dalam kesenian terbukti dapat mengumpulkan dan menyatukan semua golongan orang bahkan tidak hanya orang Muslim, bisa berkumpul dalam satu wadah yang damai. Adapun kerugian dari klaim bidah dan syirik adalah kehilangan dampak di belakangnya, yaitu hilangnya rasa kegotongroyongan dan berkumpulnya umat dalam kedamaian.

Sintren sebagaimana wayang merupakan kesenian yang kaya simbol. Simbolisme dalam asal kata dan sejarah dimaknai sebagai berikut. Sintren dapat dianggap dari asal kata sanskerta Si dan Tren. Si merupakan sebutan untuk benda, tren bermakna menghentikan. Maka Sintren adalah media menghentikan atau menetralisir sesuatu, dalam hal ini yaitu kesenangan anak yang belum mengerti batas. Pada 
riwayat cerita Sintren, ibu (orang tua) Sulandono tidak setuju anaknya akan menikahi Sulasih karena tidak sekufu. Sekufu (sepadan) ini memang hanyalah menjadi anjuran atau syarat saja yang tidak sampai menjadi rukun nikah, tetapi menjadi pertimbangan untuk mewujudkan pernikahan yang baik. Pada akhirnya Sulandono memilih bertapa. Cerita Sintren ini dapat dijadikan contoh bagi orang tua untuk mengajari anak memilih jodoh.

Simbolisme dalam pertunjukan juga banyak ditemui. Mulai dari pembakaran dupa dan kemenyan merupakan pengingat agar umat Muslim ini bisa menjadi wewangian, manusia yang wangi bagi sekitar. Dupa diedarkan sambil menebar kembang, maka manusia jangan sampai kalah dengan kembang.

Dalam pertunjukan Sintren yang merupakan tradisi pesisir, akan ditemukan suasana egaliter. Nada yang digunakan tidak lebih dari 2-3 not yang diulang-ulang, sehingga lebih dekat dan dikenal sebagaimana terbiasa mendengar deburan ombak. Konsep egaliter yang diwakili dari nada gamelan pesisir ini akan bisa dipahami lebih dalam dengan kerangka teori nilai budaya yang digambarkan dengan bagan: nilai budaya $\rightarrow$ norma $\rightarrow$ pola pikir $\rightarrow$ sikap $\rightarrow$ pola $\rightarrow$ tindakan (Simuh, 2016). Hanya saja, dalam kajian ini sengaja tidak diperluas.

Budaya bukanlah semata produk seni, setidaknya bagi Lesbumi. Budaya adalah pengamalan amal saleh dan keimanan. Seluruh amal adalah budaya, budaya identik dengan tradisi, jika tradisi diksi dari bahasa Inggris, maka 
diksi dalam bahasa Arab adalah sunnah. Maka budayatradisi juga merupakan ejawantah dari sunnah.

Masih dalam kerangka asal/akar kata, yang menghubungkan antara khaaliq (pencipta) dan khalqan (makhluk) adalah akhlaaq (perilaku). Sikap makhluk digerakkan oleh akhlak, sehingga akhlak menjadi fitrah, bukan kondisi yang dibuat. Sebagai contoh, yang dibutuhkan orang tua yang hendak mengajari kesopanan kepada anak adalah sebuah model/contoh. Sebagaimana para sahabat mencontoh nabi berperilaku setiap hari sebagai modelnya. Hal demikianlah yang mentradisi dan diteruskan dari generasi ke generasi, nabi, sahabat, tabiin, tabiit-tabiin, hingga ke kiai dan santri. Dalam mengajari kesopanan, yang lebih banyak dibutuhkan adalah contoh perilaku, bukan kata-kata. Hal ini cukup untuk mendasari munculnya taritarian dan bunyi-bunyian yang mewakili model.

Gus EA menegaskan bahwa tari identik dengan kegiatan sehari-hari. Gerak merupakan sifat jamal Allah. Orang yang menampilkan keindahan Allah sebenarnya ingin menampilkan walyatalatthaf (lemah lembut), sehingga orang yang bergerak/ penari akan perilakunya akan menjadi lemah lembut. Rumus umum ini juga menjadi sugesti, sebagaimana kemudian banyak diyakini masyarakat bahwa saat menari, akan muncul inner beauty penari dan sifat percaya diri. Penari Sintren tidak bisa disentuh laki-laki, sebagai ajaran agar wanita tidak sembarang disentuh lakilaki yang bukan mahramnya.

Pemaknaan kesenian memang merupakan asumsi yang dibangun agar penonton atau masyarakat bisa 
terbantu memahami dan menghargai. Pendekatan tasawuf untuk memberikan makna esensi kesenian akan lebih mudah diterapkan. Penampilan Sintren dapat dianggap sebagai harmoni dari komunitas sebagai penyajian yang terbaik, sebagaimana kunci ibadah, karena ibadah adalah penyajian hamba kepada tuhan. Termasuk penari Sintren yang kesurupan sebagai perlambang untuk menghilangkan eksistensi diri manusia, bahwa saat memberikan persembahan/penyajian, karakter manusia ditiadakan, agar bisa murni sebagai hamba yang menghadap tuhan, lebih jauh lagi sebagaimana konsep tajalli.

Saat temohan atau saweran, dapat dikaitkan dengan wahyu Alquran: fa alhamahaa fujuurahaa wa taqwaahaa, bahwa wahyu ada yang baik dan ada yang buruk. Saat Sintren disawer (ini mewakili kejelekan) penari Sintren akan berhenti. Setelah kondisi fujuur (jelek) penari dimasukkan kembali ke dalam kurungan. Kemudian saat diiringi kembali dengan gamelan (mewakili yang baik) penari bisa sadar kembali dan menari lagi. Kurungan melambangkan bentuk dzahir manusia, sedangkan yang dikurung adalah ruhnya. Hal ini mirip dengan proses tahalli, takhalli, dan tajalli, yang diwujudkan dalam 3 mantra: masuk kurungan, berubah, dan kembali ke asal. Satu lagi tambahan pembeda dalam Sintren santri, bahwa penari hanya akan roboh jika dilempar di mengenai bagian dahi, hal ini karena dahi merupakan tempat sujud, tempat suci yang tidak boleh dikotori dengan hal duniawi.

Menafsirkan dalil wa maa khalaqtu ljinnawal insa illaa liya'buduun dalam bentuk Sintren sebagai berikut. Ibadah 
adalah bentuk pertunjukan, bahkan salat jadi pertunjukan jika niatnya bukan lillahi ta'ala. Kesadaran untuk menjadi hamba Allah tidak hanya pertunjukan, tetapi persembahan terbaik bagi manusia dan sekalian alam.

$$
\text { و و و و و ما ما خلقت الجن و الإنس إلا ليعبدون }
$$

Bahwa manusia dan jin tidak diciptakan kecuali untuk beribadah. Sementara, doa adalah pusatnya ibadah, maka jin dan manusia dicipta untuk berdoa. Sementara salat merupakan bentuk doa, maka bisa pula dimaknai jin dan manusia dicipta untuk melakukan salat. Sedangkan salat bertujuan untuk mengingat Allah, maka jin dan manusia dicipta untuk selalu mengingat Allah. Zikir yang paling utama adalah laa ilaaha illallah yang merupakan kalimat tauhid, maka jin dan manusia dicipta untuk mengesakan Allah. Oleh karenanya, pertunjukan Sintren dapat dimaknai sebagai persembahan terbaik atas nikmat Allah.

Semua pemaknaan simbol tersebut adalah untuk memudahkan para penonton memahami esensi seni Sintren. Meskipun demikian, bagi penonton yang tidak mempercayai hal yang dekat dengan esensi mistis tersebut boleh saja menganggap Sintren sebagai pertunjukan seni semata, 
seni untuk seni, yang memiliki keindahannya sendiri. Gus EA juga memberikan keterangan bahwa Sintren santri ini bisa dikatakan murni teaterikal. Semua penampilan adalah berdasar latihan. Bahkan kondisi yang mirip kesurupan, dalam dunia teater sangat mudah dikenal dengan kondisi trance saat penari/ pemeran menyatu dan menjiwai perannya dengan baik.

Lebih lanjut, Gus EA menambahkan bahwa program Lesbumi Pekalongan ke depan adalah lebih membumikan kesenian Sintren (santri) kepada masyarakat, yaitu melalui pelatihan di tiap sekolah maarif. Harapan ke depan, di tiap sekolah terdapat penari Sintren sehingga kesenian Sintren tidak punah. Dalam penampilan Sintren santri, teruatama untuk Sintren anak, bacaan mantra ditiadakan, hanya menetapkan musik agar tidak menghilangkan jejak kesejarahan di antaranya tiga lagu utama: SulasihSulandono pada bagian awal, Turun Sintren saat dalam kurungan, dan Kembang ilalang saat keluar kurungan.

\section{Masihkah Sintren Asli Pekalongan?}

Setiap karya manusia lahir dalam kondisi historis dan kondisi sosial tertentu yang tidak akan pernah dapat ditangkap tanpa mencoba memahami prinsip-prinsip struktur umum di balik karya tersebut. Bagi kebanyakan orang memang permasalahan makna menjadi lebih dipentingkan daripada perkembangan sejarah dari suatu mitos dan tradisi, meskipun pemaknaan terhadap mitos dan tradisi bernuansa religi merupakan hal yang susah dilogikakan. Misteri pemaknaan mitos pada akhirnya tidak 
menyalahi rasio pikir manusia, melainkan akan melengkapi dan menyempurnakannya (Cassirer, 1987).

Penulis sudah kenalkan konsep Sintren awal baik dari penjelasan para penulis sebelumnya dari berbentuk artikel maupun novel. Bahwasanya Sintren Pekalongan muncul sebagai karya seni rakyat dengan ciri-cirinya tersendiri yang memiliki dasar sejarah yang erat dengan mitos. Berkembangnya masa membuat kesenian Sintren di Pekalongan mengalami perkembangan pasang-surut, modifikasi dan komodifikasi sedemikian rupa. Bahkan dari pihak Lesbumi dan DKD berupaya mempertahankannya dengan tujuan yang lebih utama sebagai pemertahanan budaya, agar tidak punah, meskipun cara yang ditempuh bisa saja mengaburkan keindahan dasar seninya yang murni. Pihak DKD dan Lesbumi memberikan tawaran pemaknaan Sintren agar lebih dapat diterima masyarakat masa kini, khususnya umat Islam yang gencar dipengaruhi oleh ajaran formalistik yang kurang lembut. Oleh karenanya, kesenian Sintren yang awalnya merupakan kesenian mistis, Sintren sebagai wadah yang berjiwa karena melibatkan roh bidadari, menjadi kurang sempurna, seakan hanya menjadi raga yang tak berjiwa. Terlebih jika Sintren dituntut untuk menjadi hiburan yang dijadikan komoditas hiburan panggung yang digabungkan dengan penampilan dangdut vulgar. Lalu masih adakah prototype kesenian Sintren yang masih dengan konsep lama, jika tidak dikatakan asli?

Terlepas dari klaim asli atau tidak, penulis menemukan pengalaman menarik saat menyaksikan penampilan 
Sintren grup AS Panjang Baru Kota Pekalongan, baik saat melihat langsung sekilas pada pertunjukan di TPI pantai Pekalongan maupun dari beberapa koleksi rekaman dalam video. Terdapat beberapa perbedaan dengan penampilan dari grup Sintren BP Sragi maupun grup Sintren santri. 1) Segi pakaian, Sintren AS dengan pakaian mirip penari remo Jawa Timur, dan para pengiring menggunakan kain dan kebaya. 2) Pawang (dukun) Sintren adalah seorang wanita. 3) Atraksi tarian Sintren AS lebih bernuansa 'kerasukan' roh. 4) Suasana kesederhanaan kesenian rakyat dan bau mistis masih terasa. 5) Koleksi lagu pengiring Sintren dengan berbahasa Jawa pesisiran sangat beragam.

Beberapa keterangan yang disampaikan $\mathrm{Bu} \quad \mathrm{M}^{15}$ selaku pengasuh grup Sintren AS yang dulunya juga seorang penari Sintren menambah keyakinan penulis bahwa Sintren grup AS dapat mewakili Sintren lama. Menurutnya, Sintren asli tidak ada yang santri, tidak ada yang berjilbab. Oleh karenanya, yang mengalami perubahan berarti sudah keluar dari pakem awal. Sekarang banyak Sintren yang sudah tidak asli. Sementara Sintren AS dari dulu-dulu -yang diajarkan simbah- baik bajunya maupun cara menarinya relatif masih sama.

Bu M membuat pembagian Sintren ke dalam dua macam: Sintren asli dan Sintren garapan. Sintren garapan dibuat tanpa magis/mistis. Grup AS mengusung Sintren asli dengan kelengkapan upakaranya, dengan bunga dan kemenyan, serta memanggil ruh bidadari. Meskipun

${ }^{15}$ Wawancara dengan Bu M, pengasuh grup Sintren AS Panjang Baru Kota Pekalongan. 
mengusung konsep asli, grup Sintren AS juga tidak akan menolak permintaan para pengundang jika menghendaki penampilan Sintren tanpa upakara dan hal magis dengan alasan semisal lokasi pertunjukan adalah lokasi wingit yang rawan, maka yang dtampilkan adalah Sintren sadar (tanpa dirasuki roh).

Pengalaman $\mathrm{Bu} \mathrm{M}$ saat dulu menjadi salah satu penari di grup AS, yang dimulai sejak ia duduk kelas 3 SMP adalah adanya keyakinan bahwa roh bidadari atau disebut roh sulasih akan mendatangi dan merasuki penari dengan sendirinya. Roh akan bisa memilih penari mana yang ingin dirasuki dan yang cocok. Berbeda dengan saat ini, roh perlu diundang dan didatangkan.

Selain keyakinan itu, dulu Sintren juga identik dengan gadis perawan, tidak bisa dan belum tersentuh laki-laki. Hal ini juga berlaku dalam pementasan, Sintren asli akan pingsan saat tersentuh laki-laki, tetapi tidak jika disentuh, dipegang, digandeng sesama perempuan atau anak kecil. Terkait hal ini pula, pawang grup Sintren AS dari dulu adalah seorang perempuan, yaitu simbah yang sampai sekarang masih sebagai pawang. Rasanya akan aneh jika yang menjadi pawang adalah laki-laki. Sedangkan pawang dipastikan berinteraksi dan bersentuhan dengan penari Sintren.

Mendengar cerita dari para penonton dan tetangga, dulu saat menari Sintren, Bu M bisa menari dalam waktu lama tanpa merasa capek, bisa satu jam tanpa henti, badannya sangat ringan, meloncat kesana kemari, naik 
turun kurungan asli dari bambu dengan mudah, bahkan di atas buyung air. Masih kata para penonton yang di dengarnya setelah menari, terdapat perbedaan aura dan wajah saat menari lebih cantik daripada aslinya. Bu M mengaku dulunya tidak memiliki bakat menari sama sekali. Justru setelah menjadi penari Sintren, ia bisa belajar menari dengan mudah bahkan bisa menjadi pelatih senam hingga saat ini.

Salah satu pengalaman lain yang dialami $\mathrm{Bu} \mathrm{M}$ saat menari Sintren di pantai Slamaran, di sana banyak ibu-ibu membawa bayi. Setelah menari selesai, kembang ronce yang dipakai menari banyak diminta ibu-ibu untuk disuapkan kepada bayi, sebagai penolak sawan. Tidak hanya bayi, seringkali juga dalam pementasan, peserta grup dan penonton ada yang kesurupan, lalu oleh pawang atau penari Sintren yang sudah sadar cukup disuapkan bunga atau kemenyan, sehingga sadar kembali dengan cepat.

Sintren saat kerasukan roh hanya bisa mendengar dan melihat, tetapi tidak bisa bicara. Oleh karena itu, pernah saat $\mathrm{Bu} \mathrm{M}$ menari, saat musiknya tidak enak atau minta ganti, ia akan dengan sendirinya berhenti. Baru saat lagunya diganti, ia kembali menari. Bahkan dulu ada pemain kendang AS yang biasa suatu saat pentas tiba-tiba pergi ke belakang untuk buang hajat, sementara kendang dimainkan oleh orang lain. Ternyata penari Sintren berhenti tidak mau menari, hingga pemain kendang yang asli datang. Dari pengalaman adanya penari Sintren yang demikian, maka akan aneh jika ada penari Sintren yang masih bisa atau bercakap-cakap saat menari. 
Gambaran penari Sintren dalam novel (Yudhistira, 2007) dengan tokoh Saraswati yang mengalami berbagai perubahan setelah menjadi penari Sintren, beberapa juga dialami oleh $\mathrm{Bu} \mathrm{M}$, termasuk pengalaman menjadi orang yang lebih peka terhadap firasat dan bisa diperlihatkan penampakan makhluk halus.

Satu aspek lagi yang membuat grup Sintren AS menurut penulis dapat mewakili Sintren lama adalah koleksi lagu dengan lirik Jawa pesisirannya yang khas. Sementara di grup Sintren lainnya ada campuran lagu berbahasa campuran Jawa-Sunda maupun bahasa Indonesia. Dalam kajian ini lirik lagu tidak dibahas mendalam karena keterbatasan kemampuan analisis penulis. Meskipun demikian, dari judul-judul yang dapat disajikan sudah sedikit mewakili pernyataan ini. Termasuk misteri salah satu lagu "bismilah" sebagai penanda dan pengakuan identitas Islami yang belum diketahui kapan mulainya, hanya diketahui dari dulu ajaran simbah pawang sudah ada. Sementara saat menikmati pertunjukan Sintren AS, penonton masih dapat merasakan suasana sinkretisme yang samar-samar.

\section{Bismilah mulai nggambang \\ Sik tak gambang kayune jati \\ Bismilah mulai nembang \\ Sik tak tembang Sintren saiki}

Judul-judul lagunya antara lain ${ }^{16}$ : Bismilah (pembuka sebelum Sintren diikat), kolang kaling (saat Sintren diikat), Sulasih-Sulandono (saat dalam kurungan), kembang

${ }^{16}$ Hasil wawancara dengan kelompok grup Sintren AS: Bu M, Pak D koordnator, dan Bu S seorang panjak/sinden Sintren. 
ketipes (saat berdandan dalam kurungan), kembang mbako (saat kurungan dibuka), blimbing krapyak (lagu cadangan kembang mbako), benting lading (lagu saat tarian Sintren mulai panas agar turun temponya), eng-eng (saat Sintren dirasuki roh anak), bajing loncat (saat Sintren atraksi), beberapa lagu hiburan (layang-layang, ayam walik, air sebuyung, dayung palembang), lir kesandung (lagus paling mistis saat Sintren siuman setelah dibalang/dilempar), engsot-sengsot (saat Sintren capek sehingga menari sambil duduk), uler kilan (lagu tambahan/pesanan untuk menolak hujan), dan kembang laos (lagu penutup saat Sintren masuk kurungan berganti baju).

\section{PENUTUP}

Sintren di tiap daerah boleh mengklaim atau diklaim sebagai Sintren asli selama memiliki dasar yang menguatkan. Sintren di Pekalongan bagi penulis memiliki kekhasan dan penguat jatidiri mereka dengan adanya sejarah ataupun dongeng tokoh pelaku Sintren Sulasih-Sulandono yang berasal dari Pekalongan. Dengan perkembangan zaman, Sintren di Pekalongan tidak dipungkiri mengalami perubahan dan pergeseran dari segi bentuk dan esensi. Terdapat Sintren yang dikemas menjadi sebuah komoditas hiburan yang dikolaborasikan dengan seni dangdut yang lebih vulgar, ada pula yang dikemas menjadi Sintren santri yang lebih Islami. Meskipun demikian, jika dicari, dibandingkan, dan dinikmati, tiap kesenian Sintren yang ditampilkan memiliki kelebihan dan kekurangan masing-masing. Pemaknaan Sintren dengan pendekatan sufistik Islami sebagaimana yang 
dilakukan oleh organisasi Lesbumi dan Dewan Kesenian Daerah membawa dampak positif untuk lebih mengenalkan dan berterima bagi masyarakat luas, termasuk menolak tuduhan bidah-syirik kaum formalistik. Akan tetapi di luar itu semua, bagi penulis, Sintren dengan konsep lama yang bernuansa mistis tradisionalis tetaplah memiliki daya tarik eksotisnya yang khas dan perlu dipertahankan keberadaannya sebagai khasanah budaya bangsa dan wujud nyata adanya dakwah lentur dalam media kesenian.

\section{DAFTAR PUSTAKA}

Achmad, S. W. 2017. Sejarah Raja-Raja Jawa Dari Kalingga Hingga Mataram Islam (1st ed.). Yogyakarta: Araska.

Aditama, L. D. 2016. Kesenian Sintren Sebagai Kearifan Lokal Ditinjau dari Metafisika Anton Bakker. Jurnal Penelitian Humaniora, Vol. 21, No. 1, 57-72.

Buku Kesenian Daerah Kota Pekalongan. 2003. Kantor Pariwisata Kota Pekalongan.

Cassirer, E. 1987. Manusia dan Kebudayaan: Sebuah Esei tentang Manusia. Jakarta: Gramedia.

Dirhamsyah, M. 2014. Pekalongan yang (tak) Terlupakan: Sebuah Katalog Warisan Budaya Pekalongan (A. Thoha, Ed.). Pekalongan: Kantor Perpusda Kota Pekalongan.

Endraswara, S. 2005. Tradisi Lisan Jawa: Warisan Abadi Budaya Leluhur (1st ed.). Yogyakarta: Narasi.

Geertz, C. 1992a. Politik Kebudayaan (1st ed.). Yogyakarta: Kanisius.

Geertz, C. 1992b. Tafsir Kebudayaan. Yogyakarta: Kanisius. 
Geertz, C. 2003. Pengetahuan Lokal (1st ed.; A. A. Mundayat, Ed.). Yogyakarta: Rumah Penerbitan Merapi.

Haeri, I. Z. 2017. Tari Sintren, Dakwah Ramah Islam ala Wali Songo. Retrieved from https://islami.co/tari-Sintrendakwah-ramah-islam-ala-wali-songo/

Hasyim, G. 2008. Dewi Lanjar. In Pekalongan Inspirasi Indonesia (pp. 301-305). Pekalongan: Pemerintah Daerah Kota Pekalongan bekerja sama dengan The Pekalongan Institute \& Kirana Pustaka Indonesia.

Ilyas, A. Z., \& Abidin, Z. 2016. Makna spiritualitas pada penari Sintren di pekalongan. Jurnal Empati, Vol. 5, No. 4, 807-811.

Kaplan, D., \& Manners, A. R. 2002. Teori Budaya. Yogyakarta: Pustaka Pelajar.

Kholil, A. 2007. Islam Jawa (Sufisme dalam Tradisi dan Etika Jawa). Jurnal El-Harakah, Vol. 9, No. 2, 86-98. https:/ / doi.org/10.18860/el.v9i2.4644

Koeswinarno, K. 2010. Memahami Masyarakat Beragama Dalam Perspektif Kebudayaan (1st ed.). Yogyakarta: Idea Press.

Mansoer, C. 2007. LESBUMI: Kini, Lampau dan Datang. Retrieved from http://majalah-pusara.blogspot. com/2007 / 07 / lesbumi-kini-lampau-dan-datangchisaan.html

Nashichuddin, A. 2006. Sufisme in Java: The Meeting Point Between Sufism and Javanese Mysticism. Jurnal El-Harakah, Vol. 8, No. 1, 43-51. https://doi. org/10.18860/el.v8i1.4613

Purwadi. 2011. Kearifan Sufisme dalam Islamisasi Jawa. Ibda, 294 
Vol. 9, No. 1, 113-125. https://doi.org/10.24090/ ibda.v9i1.33

Setyadi, R. 2005. Masa Lalu Kolonial dalam Sintren Masa Kini. In B. Susanto (Ed.), Penghiburan Masa Lalu dan Budaya Hidup Masa Kini Indonesia (pp. 235-278). Yogyakarta: Kanisius.

Simuh. 2016. Sufisme Jawa: Transformasi Tasawuf Islam ke Mistik Jawa (1st ed.). Yogyakarta: Narasi.

Sofwan, R., Wasit, \& Mundiri. 2004. Islamimasi di Jawa: Walisongo, penyebar Islam di Jawa, menurut penuturan babad (II). Yogyakarta: Pustaka Pelajar.

Thohir, M. 2011. Kata Pengantar. In R. Fauzi (Ed.), Menguak Makna Kearifan Lokal pada Masyarakat Multikultural (pp. iv-ix). Semarang: Robar Bersama.

Yudhistira, D. W. 2007. Sintren (1st ed.; A. A. Nusantaram, Ed.). Batang: PT. Grasindo. 


\section{BIBLIOGRAFI}

Achmad, S. W. 2017. Sejarah Raja-Raja Jawa Dari Kalingga Hingga Mataram Islam (1st ed.). Yogyakarta: Araska.

Adam, Aulia. 2017. Mengikuti Keseharian Generasi $Z$ Golongan Pertama. Diakses tanggal 30 September 2019 dari https://tirto.id/mengikuti-kesehariangenerasi-z-golongan-pertama-ctLk.

Aditama, L. D. 2016. Kesenian Sintren Sebagai Kearifan Lokal Ditinjau dari Metafisika Anton Bakker. Jurnal Penelitian Humaniora, Vol. 21, No. 1, 57-72.

Agung S., Leo. 2014. Tradisi Lisan sebagai Sejarah, Redefinisi Pembelajaran dalam Kurikulum 2013. Prosiding Seminar Nasional Pendidikan "Redefinisi Pembelajaran IPS/Sejarah Pada Pendidikan Dasar dan Menengah". 26 Juni 2014. 69 - 82.

Agung, Anak Agung Ktut. 1991. Kupu-Kupu Kuning yang Terbang di Selat Lombok. Denpasar: PT Upada Sastra Agus, Afdal, Bakhtaruddin Nst, M. Ismail Nst. 2013. Sastra Lisan Mantra Pengobatan Di Kenagarian Talu Kecamatan Talamau Kabupaten Pasaman Barat. Padang: Skripsi Mahasiswa FBS Universitas Negeri Padang.

Ali, Jacub, Umar, Siradz. 1998. Perubahan Nilai Upacara Tradisional Pada Masyarakat Pendukungnya di Daerah Nusa Tenggara Barat. Mataram: Bagian Proyek Pengkajian dan Pembinaan Nilai-Nilai Budaya Nusa Tenggara Barat Departemen Pendidikan dan Kebudayaan 
Anisa, Dina Fitri. 2018. 2018, Indonesia Tetapkan 225 Warisan Budaya Tak Benda. Diakses pada 19 Oktober 2019 dari https://www.beritasatu.com/ hiburan/514530/2018-indonesia-tetapkan-225warisan-budaya-takbenda.

Artini, Ni Made Rai. 2013. Menyoroti Etika Umat Hindu "Ke Pura Berpenampilan Selebritis. Skripsi: Universitas Pendidikan Ganesha Singaraja.

Ashadi. 2017. Keraton Jawa. Jakarta: UMJ Press.

Astuti, Indri Yuni. 2013. "Makna Simbolik Ragam Gerak Tari Terbang Rudat Kabupaten Pasuruan. "Skripsi, Jurusan Seni dan Desain, Fakultas Sastra, Universitas Negeri Malang

Azra, Azyumardi. 2002. Islam Nusantara: Jaringan Global dan Lokal. Bandung: Mizan.

Badan Pusat Statistik. 2018. Statistik Gender Tematik: Profil Generasi Milenial Indonesia. Kementerian Pemberdayaan Perempuan dan Perlindungan Anak.

Bagus, I Gusti Ngurah. 1990. "Kebudayaan Bali," Dalam Koentjaraningrat, Manusia dan Kebudayaan di Indonesia. Jakarta: Penerbit Djambatan.

Baried, Siti Baroroh dkk. 1994. Pengantar Teori Filologi.Yogyakarta: Penerbit Badan Penelitian dan Publikasi Fakultas Seksi Filologi Fakultas Sastra Universitas Gadjah Mada.

Baried, Siti Baroroh.1985. Pengantar Filologi. Jakarta: Pusat Pembinaan dan Pengembangan Bahasa.

Bartholomew, John Ryan. 2001. Alif Lam Mim Kearifan Masyarakat Lombok (Alif Lam Mim: Reconciling Islam, 
Modernity and Tradition in an Indonesian Kampung 1999). terj. Imron Rosyidi. Yogyakarta: Tiara Wacana Bhatia, Namit (ed.). 1992. The Oxford Companion to the English Language. Np.

Budarsa, Gede. tt. Karakteristik Budaya Komunitas Pegayaman Buleleng Bali. Denpasar: Program Studi Antropologi Fakultas Sastra dan Budaya Universitas Udayana.

Buku Kesenian Daerah Kota Pekalongan. 2003. Kantor Pariwisata Kota Pekalongan.

Burhani, Ahmad Najib. 2010. Muhammadiyah Jawa. Jakarta: al-Wasat.

Burhanuddin, Mamat S. 2006. Hermeneutika al-Qur'an ala Pesantren. Jakarta: UII Pres.

Carey, Peter. 1976. The Origins of the Java War (1825-30). The English Historical Review, Vol. 91, No. 358. . 1978. "The Residency Archive of Jogjakarta," dalam Indonesia, Vol. 25 (April). - 2011. Kuasa Ramalan: Pangeran Diponegoro dan Akhir Tatanan Lama di Jawa, 1785 - 1855 jilid 1 - 3. Diterjemahkan oleh Parakitri T. Simbolon. Jakarta: Kepustakaan Populer Gramedia, KITLV-Jakarta, Arsari Group, Aseasuk, Fadli Zon Library.

Cassirer, E. 1987. Manusia dan Kebudayaan: Sebuah Esei tentang Manusia. Jakarta: Gramedia.

Coulson, J et.al. 1978. The New Oxford Illustrated Dictionary. England: Christian Brann Limited Cirencester.

Damami, Muhamad. 2002. Makna Agama dalam masyarakat Jawa. Yogyakarta: LESFI. 
Danandjaja, James. 1984. Folklore Indonesia. Jakarta: Grafiti Press.

. 1997. Folklor Indonesia: Ilmu Gosip, Dongeng dan Lain-lain. Jakarta: Pustaka Utama Grafiti. . 2015. Pendekatan Folklor dalam Penelitian BahanBahan Tradisi Lisan. Dalam Pudentia MPSS (ed.), Metodologi Kajian Tradisi Lisan Edisi Revisi. Jakarta: Yayasan Pustaka Obor Indonesia.

Depdikbud. 1985. Kamus Besar Bahasa Indonesia. Jakarta: Balai Pustaka

Dinas Perhubungan dan Pariwisata Kabupaten Lombok Timur.2001. Atraksi Budaya Kabupaten Lombok Timur. Selong: Dinas Perhubungan dan Pariwisata Kabupaten Lombok Timur

Dirhamsyah, M. 2014. Pekalongan yang (tak) Terlupakan: Sebuah Katalog Warisan Budaya Pekalongan (A. Thoha, Ed.). Pekalongan: Kantor Perpusda Kota Pekalongan.

Drewes, G.W.J. 1969. The Admonition of Seh Bari, A $16^{\text {th }}$ Century Javanese Muslim Text, Attributed to the Saint of Bonang, Redited and Translated with an Inroduction. Martinus Nijhoff: The Hague.

Duija, I Nengah. 2005. "Tradisi Lisan, Naskah dan Sejarah." Jurnal Wacana. Vol 7 No.2

Dundes, Alan. 1965. The Study of Folklore. London: PrenticeHall International, Inc.

Ekoputro, Z. A. (Ed.). 2011. Berpeluh Berselaras BudhisMuslim Meniti Harmoni (1st ed.). Depok: Penerbit Buku Kepik Ungu.

Endraswara, S. 2005. Tradisi Lisan Jawa: Warisan Abadi Budaya Leluhur (1st ed.). Yogyakarta: Narasi. 
.2009. Metodologi Penelitian Folklor. Yogyakarta: Media Pressindo.

. 2011. Metodologi Penelitian Tradisi Lisan. Yogyakarta: Kanwa Publisher

Fauzan, Ahmad. 2018. Sistem Pertukaan Orang Sasak dalam Prosesi Sorong Serah Ajikrama. Sangkep Jurnal Kajian Sosial Keagamaan. Vol 1 No. 1 Januari-Juni 2018: 34-48.

Florida, Nancy K. 1987. "Reading the Unread in Traditional Javanese Literature," Indonesia, Vol. 44 (Okt). . 1995. Writing the Past Inscribing the Future: History as Prophecy in Colonial Java. Durham: Duke University Press.

- 1997. "Pada Tembok Keraton Ada Pintu: Unsur Santri dalam Dunia Kepujanggaan "Klasik" di Keraton Surakarta.” Dalam Karsono H Saputra (ed), Tradisi Tulisan Nusantara. Jakarta: Masyarakat Pernaskahan Nusantara.

Geertz, C. 1992a. Politik Kebudayaan (1st ed.). Yogyakarta: Kanisius.

. 1992b. Tafsir Kebudayaan. Yogyakarta: Kanisius.

. 2003. Pengetahuan Lokal (1st ed.; A. A. Mundayat, Ed.). Yogyakarta: Rumah Penerbitan Merapi.

. 1976. The Religion of Java. Chicago: University of Chicago Press.

Generasi. Diakses tanggal 30 September 2019 dari https:// kbbi.kemdikbud.go.id/entri/generasi.

Goodman, Douglas J dan Ritzer, Geogre. 2011. Teori Sosiologi Modern. Jakarta : Kencana.

Gunawan, H. 2017. Pendidikan Karakter Konsep dan Implementasi. Bandung: Alfabeta. 
- 1998. Masuknya Islam di Bali, dalam Senang Bermuhammadiyah. Denpasar: Penerbit Media Guru Denpasar.

Gustina, A., A. V. S. Hubeis, and S. Riyanto. 2008. "Jaringan Komunikasi Dan Peran Perempuan Dalam Mempertahankan Budaya Rudat(StudiPada Masyarakat Desa Negeri Katon, Kecamatan Negeri Katon, Lampung Selatan)." Jurnal Komunikasi Pembangunan 6 (1).

Haeri, I. Z. 2017. Tari Sintren, Dakwah Ramah Islam ala Wali Songo. Retrieved from https://islami.co/tari-sintrendakwah-ramah-islam-ala-wali-songo/

Halim, Abdul (ed.). 2005. Fikih Hubungan Antar Agama. Jakarta: Ciputat Press.

Haryanto, Joko Tri. 2018. Nilai Kerukunan pada Cerita Dayuhan-Intingan di Kabupaten Tapin Kalimantan Selatan. Jurnal Smart Volume 4, No 1.

Haryati, Sri. 2017. Pendidikan Karakter dalam Kurikulum 2013. FKIP-UTM. Diakses pada 11 September 2019 dari https://lib.untidar.ac.id/wp-content/ uploads / 2017 / 01 / Pendidikan-Karakter-dalamkurikulum.pdf.

Hasyim, G. 2008. Dewi Lanjar. In Pekalongan Inspirasi Indonesia (pp. 301-305). Pekalongan: Pemerintah Daerah Kota Pekalongan bekerja sama dengan The Pekalongan Institute \& Kirana Pustaka Indonesia.

Hasyim, Wayan. 2006. Sejarah Singkat Desa Pegayaman Kecamatan Sukasada Provinsi Bali. Pegayaman : Tanpa Penerbit.

Hidayatulloh, Taufik. 2018. Memahami Perilaku Generasi Milenial. Diakses tanggal 30 September 2019 dari 
https://akurat.co/id-372391-read-memahamiperilaku-generasi-milenial.

Hikmah, Fitrotul dan Roihanah. 2017. A Javanese Panji

Romance: Analisis Struktur Cerita Panji Pada Naskah Wangbang Widèya. Jurnal Penelitian IlmAtmadja, $N$. B. 2010. Ajeg Bali Gerakan, Identitas Kultural, dan Globalisasi. Yogyakarta: LKiS.

Hobsbawn, Eric. 1983. "Introduction: Invention Traditions."

Dalam Eric Hobsbawn dan Terence Ranger (ed.), The Invention of Tradition. Cambridge: Cambridge University Press.

Hikmah, Fitrotul dan Roihanah. 2017. A Javanese Panji Romance: Analisis Struktur Cerita Panji Pada Naskah Wangbang Widèya. Jurnal Penelitian Ilmiah Intaj, Vol.01 No.02 : 29-46.

Ikram, Achadiati. 1980. Hikayat Sri Rama Suntingan Naskah disertai Telaah Amanat dan Struktur. Jakarta: Universitas Indonesia.

Ilyas, A. Z., \& Abidin, Z. 2016. Makna spiritualitas pada penari sintren di pekalongan. Jurnal Empati, Vol. 5, No. 4, 807-811.

Jorgensen, Marianne W., Louise J. Phillips. 2007. Analisis

Wacana: Teori dan Metode. Diterjemahkan oleh Imam

Suyitno, Lilik Suyitno dan Suwarna. Yogyakarta: Pustaka Pelajar.

Kaplan, D., \& Manners, A. R. 2002. Teori Budaya. Yogyakarta: Pustaka Pelajar.

Kawedanan Hageng Panitrapura Karaton Ngayogyakarta Hadiningrat. 2010. Pranatan Lempah-Lempah Pesowanan/Parakan Ngabekten Karaton 
Tradisi Lisan, Pendidikan Karakter, dan Harmoni Umat Beragama di Era 4.0

Ngayogyakarta Hadiningrat Tahun Dal 1943 Utawi 2010 Ing Dinten Jemuah Legi sarto Setu Pahing Tanggap Kaping 1 sarto 2 Sawal Dal 1943 utawi Suryo Kaping 10 sarto 11 September 2010. Yogyakarta: Kawedanan Hageng Panitrapura Karaton Ngayogyakarta Hadiningrat.

Kersten, Carol. 2017. Mengislamkan Indonesia: Sejarah Peradaban Islam di Nusantara. Diterjemahkan oleh Zia Anshor. Tangerang Selatan: Penerbit Baca.

Khalim, Samidi. 2009. Tradisi Lisan Masyarakat Jawa.

Semarang: Primamedia Press

Kholil, A. 2007. Islam Jawa (Sufisme dalam Tradisi dan Etika Jawa). Jurnal El-Harakah, Vol. 9, No. 2, 86-98. https://doi.org/10.18860/el.v9i2.4644

Koentjaraningrat. 1985. Javanese Culture. Oxford dan New York: Oxford University Press.

Koesoema A, Doni. 2012. Pendidikan Karakter Utuh dan Menyeluruh. Yogyakarta: Kanisius.

Koeswinarno, K. 2010. Memahami Masyarakat Beragama Dalam Perspektif Kebudayaan (1st ed.). Yogyakarta: Idea Press.

Kumar, Ann. 1980. Javanese Court Society and Politics in the Late Eighteenth Century: The Record of the Lady Soldier. Part I: The Religious, Social, and Economic Life of the Court. Indonesia Vol. 29 (April).

Kuniawan, Yusuf Wawan. 2012. "Aspek Pendidikan Nilai Religius dalam Tradisi Budaya Rodad (Studi Kasus di Desa Kalimati Kecamatan Juwangi Kabupaten Boyolali)." Skripsi Universitas Muhammadiyah Surakarta. 
Kurniawan. 2001. Semiologi Roland Barthes. Magelang: Indonesia Terra

Kusmayati, AM Hermien dan Suminto A Sayuti. 2014. Eksistensi Sastra Lisan Mamaca Di Kabupaten Pamekasan, Madura. Jurnal Litera Volume 13 No. 1 April 2014.

Lauer, Robert H. 1989. Perspektif Tentang Perubahan Sosial. Jakarta : Bina Aksara.

. 2003. Perspective on Social Change, terj Alimandan. Jakarta: Rineka Cipta.

Lindsay, J, dkk, Katalog Induk Naskah-Naskah Nusantara Jilid 2: Kraton Yogyakarta. Jakarta: Yayasan Obor Indonesia, 1994.

Lombard, Denys. 2005. Nusa Jawa: Silang Budaya. Kajian Sejarah Terpadu. Bagian III: Warisan Kerajaan-kerajaan Konsentris. Diterjemahkan oleh Winarsih Partaningrat Arifin, Rahayu S. Hidayat, Nini Hidayati Yusuf. Jakarta: Gramedia Pustaka Utama, Forum Jakarta-Paris, EFEO.

Maharkesti, R.A. 2000. Tradisi Ngabekten di Kraton Yogyakarta. Patra-Widya: Seri Penerbitan Penelitian Sejarah dan Budaya, Vol. 1, No. 1.

Maharsi, Resi. 2010. Islam Melayu Vs Jawa Islam: Menelusuri Jejak Karya Sastra Sejarah Nusantara. Yogyakarta: Pustaka Pelajar.

Mansoer, C. 2007. LESBUMI: Kini, Lampau dan Datang. Retrieved from http://majalah-pusara.blogspot. com/2007 / 07 / lesbumi-kini-lampau-dan-datangchisaan.html

Margana, S. 2004. Kraton Surakarta dan Yogyakarta: 17691874. Yogyakarta: Pustaka Pelajar. 
Marianto, M. Dwi. 1997. Menempa Quanta Mengurai Seni. Yogyakarta: BP ISI Yogyakarta.

Marihandono, Djoko, Harto Juwono. 2008. Sultan Hamengkubowono II Pembela Tradisi dan Kekuasaan Jawa. Yogyakarta: Banjar Aji Production,

Marzuki. Tt. Konsep Dasar Pendidikan Karakter. Makalah tidak diterbitkan.

Milenial. Diakses tanggal 30 September 2019 dari https:// kbbi.kemdikbud.go.id/entri/milenial.

MPSS, P. (Ed.). (2015). Metodologi Kajian Tradisi Lisan. Yayasan Obor Indonesia.

Muljana, Slamet. 1997. Tafsir Sejarah Nagara Kretagama. Jakarta: Balai Pustaka dan Departemen Urusan Research Nasional.

Mulyasa, E. 2012. Manajemen Pendidikan Karakter. Jakarta: Bumi Aksara.

Mulyono et. all. 1980. Sejarah Masuknya Islam di Bali. Denpasar: Proyek Penelitian Pemda Tingkat 1 Provinsi Bali.

Murniah, Dad. n.d. 2018. "Sirkumlokusi dalam Folklor Indonesia sebagai Dasar Pembangunan Karakter Bangsa" Accessed September 3, 2019. https://www. academia.edu / 3850827 / Sirkumlokusi_Dalam_ Folklor_Indonesia_Sebagai_Dasar_Pembangunan_ Karakter_Bangsa_Oleh_Dra._Dad_Murniah_M.Hum._ Badan_Pengembangan_dan_Pembinaan_Bahasa.

Nafsiah, Lalu. 2015. Dokumentasi/Katalog Museum Negeri NTB: naskah tidak diterbitkan

Nashichuddin, A. 2006. Sufisme in Java: The Meeting Point Between Sufism and Javanese Mysticism. 
Jurnal El-Harakah, Vol. 8, No. 1, 43-51. https://doi. org/10.18860/el.v8i1.4613

Nuarca, I Ketut. 2017. Kakawin Ramayana. Denpasar: Program Studi Sastra Jawa Kuno Fakultas Ilmu Budaya Universitas Udayana.

Paeni, Mukhlis. 2009. Sejarah Kebudayaan Indonesia. Jakarta: Rajawali Press.

Pageh, I Made. 2018. Kearifan Sistem Religi Lokal Dalam Mengintegrasikan Umat Hindu-Islam Di Bali. Jurnal Sejarah Citra Lekha Jurusan Sejarah Fakultas Humaniora, Universitas Diponegoro, Vol. 3, No. 2.

Panji, I Gusti Ngurah. 1956. Sejarah Buleleng. Singaraja: Pemerintah Kabupaten Buleleng "UPTD Gedong Kirtya”. Parimartha, I Gde et all. 2012. Bulan Sabit di Pulau Dewata Jejak Kampung Islam Kusamba-Bali. Yogyakarta: Pusat Studi Agama dan Lintas Budaya CRCS Universitas Gadjah Mada.

Peraturan Menteri Pendidikan dan Kebudayaan RI Nomor 20 Tahun 2018 tentang Penguatan Pendidikan Karakter Pada Satuan Pendidikan Formal.

Peraturan Presiden RI Nomor 87 Tahun 2017 tentang Program Penguatan Pendidikan Karakter.

Peursen, CA van. 1988. Strategi Kebudayaan. Yogyakarta: Kanisius.

Poerbatjaraka, Tardjan Hadidjaja. 1952. Kepustakaan Djawa. Jakarta: Djambatan.

Prasetyo, B., \& Trisyanti, U. 2019. "Strategi Pembangunan Nasional Menghadapi Revolusi Industri 4.0." Dalam Prosiding SEMATEKSOS 3 Revolusi Industri 4.0 Dan Tantangan Perubahan Sosial, 22-27. 
Pudentia. 2015. "Pengantar Bagian Pertama."Dalam Pudentia (ed), Metodologi Kajian Tradisi Lisan. Jakarta: Yayasan Pustaka Obor Indonesia dan Asosiasi Tradisi Lisan.

Purwadi. 2011. Kearifan Sufisme dalam Islamisasi Jawa. Ibda, Vol. 9, No. 1, 113-125. https://doi.org/10.24090/ ibda.v9i1.33

Putra, Yanuar Surya. 2016. Theoritical Review: Teori Perbedaan Generasi. Jurnal Among Makarti Vol. 9 No. 18, Desember 2016, hlm. 123 - 134.

Rahman, N., \& Adiwimarta, S. S. (Eds.). 1999. Antologi Sastra Daerah Nusantara; Cerita Rakyat Suara Rakyat (1st ed.). Yayasan Obor Indonesia.

Ramli, Y. M. 2012. Agama dalam Tentukur Antropologi Simbolik Clifford Geertz. International Journal of Islamic Thought, 1(June), 62-73. Retrieved from http:// www.ukm.my/ijit/IJIT Vol 1 2012/8Yusri.pdf

Ratmadja, Lalu. 2011. Bahan Ajar Muatan Lokal Budaya Sasak SMP/Mts Kelas IX. CV Gumi Sasak: Pringgabaya Lombok Timur

Ratna, Nyoman Kutha. 2014. Peranasn Karya Sastra, Seni, dan Budaya dalam Pendidikan Karakter. Yogyakarta: Pustaka Pelajar.

Redaksi Batok. 2016. 5 Permainan Tradisional dari Indonesia yang Bisa Kamu Mainin di android. Diakses pada 20 Oktober 2019 dari https://www.batok. co/2016/03/17/5-permainan-tradisional-dariindonesia-yang-bisa-kamu-mainin-di-android/

Republika. 2016. Mengenal Generasi Millennial. Diakses tanggal 30 September 2019 dari https://www. republika.co.id/berita/koran/inovasi/16/12/26/ 


\section{ois64613-mengenal-generasi-millennial.}

Ricklefs, M.C. 1974. Jogjakarta Under Sultan Mangkubumi 1749 - 1792. A History of the Division of Java. London: Oxford University Press. . 1991. Sejarah Indonesia Modern. Yogyakarta: Gadjah Mada University Press.

. 1998. The Seen and Unseen Worlds in Java: History, Literature and Islam in the Court of Paku Buwono II 1726 - 1749. Honolulu: Allen \& Unwin and University of Hawaii Press.

Ricklefs, M.C., P. Voorhoeve. 1977. Indonesian Manuscripts in Great Britain: A Catalogue of Manuscripts in Indonesian Languages in British Public Collection. London: Oxford University Press.

Riyadi, Slamet. Edi Sedyawati dkk. 2001. "Kasultanan," dalam Sastra Jawa: Suatu Tinjauan Umum, eds. Jakarta: Pusat Bahasa dan Balai Pustaka.

Rohidi, T. R. 2018. Tradisi Lisan Sebagai Pendidikan Karakter Refleksi Paradigmatik dalam Konteks kebudayaan. Np. Rosana, Francisca Christy. 2019. 17 Pengusaha Milenial Indonesia Masuk Daftar Berprestasi Forbes. Diakses pada 11 September 2019 dari https://bisnis.tempo. co/read/1192923/17-pengusaha-milenial-indonesiamasuk-daftar-berprestasi-forbes $/$ full\&oview $=$ ok.

Rusyana, Yus. 1982. Peranan dan Kedudukan Sastra Lisan dalam Pembangunan Sastra Indonesia. Jakarta: Seminar Mendikbud.

Saleh, S., \& Anshori, Y. (Eds.). 2002. Sejarah Keberadaan Umat Islam di Bali. Denpasar: MUI Denpasar.

Santosa, Elizabeth T.. 2017. 7 Karakkteristik Generasi $Z$ 
yang Perlu Kamu Tahu. Diakses pada 01 Oktober 2019 dari https://kumparan.com/@,kumparannews/7karakteristik-generasi-z-yang-perlu-kamu-tahu

Satyananda, I. M. 2014. Kearifan Lokal Masa Tua Dan Kaitannya Dengan Pendidikan Karakter Bangsa Di Kabupaten Karangasem Bali. Yogyakarta: Ombak.

Sedyawati, Edi. 2014. Kebudayaan di Nusantara dari Keris, Tor-tor, sampai Industri Budaya. Depok: Komunitas Bambu.

Setyadi, R. 2005. Masa Lalu Kolonial dalam Sintren Masa Kini. In B. Susanto (Ed.), Penghiburan Masa Lalu dan Budaya Hidup Masa Kini Indonesia (pp. 235-278). Yogyakarta: Kanisius.

Shils, Edward Albert. 1981. Tradition. Chicago: The University of Chicago Press.

Shubhi, Muhammad. 2013. Sesengak sebagai Local Genius Masyarakat Sasak dalam Pembangunan Karakter. Dalam Folklor dan Folklife dalam Kehidupan Dunia Modern, Kesatuan dan Keberagaman. Endraswara (ed). Yogyakarta: Ombak

Sibarani, R. 2013. Revitalisasi Folklor Sebagai Sumber Kearifan Lokal. Dalam S. Endraswara, Folklor dan Folklife dalam Kehidupan Dunia Modern. Yogyakarta: Ombak.

Sibarani, Robert. 2013. Revitalisasi Folklor Sebagai Sumber Kearifan Lokal. Dalam Endraswaram Suwardi (ed,), Folklor dan Folklife dalam Kehidupan Dunia Modern. Yogyakarta: Ombak

Simatupang, Lono. 2013. Pergelaran: Sebuah Mozaik Penelitian Seni-Budaya. Yogyakarta: Jalasutra.

Simuh. 1988. Mistik Islam Kejawen Raden Ngabehi 338 
Ranggawarsita: Suatu Studi terhadap Serat Wirid Hidayat Jati. Jakarta: Universitas Indonesia Press. . 2016. Sufisme Jawa: Transformasi Tasawuf Islam ke Mistik Jawa (1st ed.). Yogyakarta: Narasi.

Sofwan, R., Wasit, \& Mundiri. 2004. Islamimasi di Jawa: Walisongo, penyebar Islam di Jawa, menurut penuturan babad (II). Yogyakarta: Pustaka Pelajar.

Sudirman dkk. 2011. Belajar Menjadi Pembayun. KSU Prima Gama bekerjasama dengan Pusat Studi dan kajian Budaya: Pringgabaya Lombok Timur

Sugiyono. 2011. Metode Penelitian Kuantitatif Kualitatif dan $R \& D$. Bandung: Alfabeta

Sulistyorini, D., \& Andalas, F. E. 2017. Sastra Lisan Kajian Teori dan Penerapannya dalam Penelitian. Malang: Madani.

Sulistyorini, Dwi, Andalas, Fajar Eggy. 2017. Sastra Lisan Kajian Teori dan Penerapannya dalam Penelitian. Malang: Madani

Supomo, S. 1977. Arjunawijaya A Kakawin of Mpu Tantular. Netherland: Koninklijk Instituut Voor Taal, Land, en Volkkenkunde.

Suwitha, I Putu Gede. 2019. Wacana "Kerajaan Majapahit Bali: Dinamika Puri Dalam Pusaran Politik Identitas Kontemporer". Jurnal Sejarah Citra Lekha Jurusan Sejarah Fakultas Humaniora, Universitas Diponegoro, Vol. 4, No. 1.

Steenbrink, Karel A. 1984. Beberapa Aspek tentang Islam di Indonesia Abad ke-19. Jakarta: Bulan Bintang. - 1988. Mencari Tuhan dengan Kacamata Barat 1. Yogyakarta; Sunan Kalijaga Press.

. 1993. Dutch Colonialism and Indonesia Islam: 
Tradisi Lisan, Pendidikan Karakter, dan Harmoni Umat Beragama di Era 4.0

Contacts and Conflicts (1596 - 1950). Amsterdam and Atlanta: Editions Rodopi BV.

Sztopmpa, Piotr. 2010. Sosiologi Perubahan Sosial. Jakarta : Prenada Media Group.

Tatu, Robin.1999. I Gusti Putu Jelantik's Babad Buleleng Placed within Historical Context. A Journal of the Southeast Asian Studies Student Association, Vol. 3, Fall.

Tepas Tandha Yekti. 2017. Garebeg. Diambil dari https:// www.kratonjogja.id/hari-besar-islam/8/garebeg. Diunduh pada 25 Februari 2019.

. 2017. Syiar Islam melalui Sekaten. Diambil dari https://www.kratonjogja.id/hari-besar-islam/12/ syiar-islam-melalui-sekaten. Diunduh pada 23 Februari 2019.

- 2017. Tata Ruang dan Bangunan Kawasan Inti Keraton Yogyakarta. Diambil dari https://www. kratonjogja.id/tata-rakiting-wewangunan/4/ tata-ruang-dan-bangunan-kawasan-inti-keratonyogyakarta. Diunduh pada 8 Maret 2019.

- 2018. Garebeg Sawal Dal 1951, Tradisi Perayaan Idul Fitri Keraton Yogyakarta. Diambil dari https:// www.kratonjogja.id/peristiwa/50/garebeg-sawal-dal1951-tradisi-perayaan-idulfitri-keraton-yogyakarta. Dinduh pada 21 Februari 2019.

- 2018. Ngabekten Dal 1951, Bentuk Bakti Kepada Sultan. Diambil dari https://www.kratonjogja.id/ peristiwa/51/ngabekten-dal-1951-bentuk-baktikepada-sultan. Diunduh pada 21 Februari 2019. .2018. Mas Bekel Ngabdul Wahab, Pemilahara Nilai- 
nilai Islam Keraton Yogyakarta. Diambil dari https:// www.kratonjogja.id/ragam/18/mas-bekel-ngabdulwahab-pemelihara-nilai-nilai-islam-keratonyogyakarta. Diunduh pada 8 Maret 2019.

.2018. Biodata. Diambil dari https://www. kratonjogja.id/biodata. Diunduh pada 1 November 2019

Thohir, M. 2011. Kata Pengantar. In R. Fauzi (Ed.), Menguak Makna Kearifan Lokal pada Masyarakat Multikultural (pp. iv - ix). Semarang: Robar Bersama.

Titib, I Made. 2003. Teologi dan Simbol-Simbol dalam Agama Hindu. Surabaya: Badan Litbang Parisade Hindu Dharma Indonesia Pusat bekerjasama dengan Paramita.

Tytler, Lord Alexander Fraser Woodhouselee. 1797. Essay on the Principles of Translation. London: Printed for Cadell and W. Davies and W. Creech Edinburgh.

Vansina, J. 2014. Tradisi Lisan Sebagai Sejarah. Yogyakarta: Penerbit Ombak.

Wicaksono, Kurniawan A. 2018. Tahukan Berapa Jumlah Warisan Budaya Tak Benda Milik Indonesia. Diakses pada 19 Oktober 2019 dari https://kabar24.bisnis. com/read/20180226/15/742973/tahukah-berapajumlah-warisan-budaya-tak-benda-milik-indonesia.

Woodward, Mark R. 1998. "Pandahuluan: Indonesia, Islam dan Orientalisme: Sebuah Wacana yang Melintas." Dalam Mark R Woodward (ed), Jalan Baru Islam: Memetakan Paradigma Mutakhir Islam Indonesia. Bandung: Mizan. . 2011. Java, Indonesia and Islam. New York: Springer. 
. 2012. Islam Jawa: Kesalehan Normatif versus Kebatinan. Diterjemahkan oleh Hairus Salim HS. Yogyakarta: LKiS.

Yahya, M. 2018. Era Industri 4.0: Tantangan dan Peluang Perkembangan Pendidikan Kejuruan Indonesia. Disampaikan pada Sidang Terbuka Luar Biasa Senat Universitas Negeri Makassar Tanggal 14 Maret 2018. Yudhistira, D. W. 2007. Sintren (1st ed.; A. A. Nusantaram, Ed.). Batang: PT. Grasindo.

Zakaria, Fath. 1998. Mozaik Budaya Orang Mataram. Mataram: Yayasan Sumurmas al-Hamidy

Zakaria, Lalu Alfian. 2018. Tradisi Sorong Serah Aji Krama: Upaya Memperkuat Hubungan Keluarga Suku Sasak. De Jure, Jurnal Hukum dan Syariah. Vol. 10 No. 2, 2018: $81-88$ 


\section{BIOGRAFI SINGKAT PENULIS}

Agus Iswanto adalah peneliti ahli madya pada Balai Litbang Agama Semarang. Studi sarjana stratata 1 (S1) di Jurusan Bahasa dan Sastra Arab, Fakultas Adab dan Humaniora UIN Sunan Kalijaga Yogyakarta. Selanjutnya menyelasikan studi strata dua (S2) di Sekolah Pascasarjana UIN Syarif Hidayatullah Jakarta dengan spesialisasi filologi naskah keagamaan dan pengkajian Islam. Beberapa karya yang baru-baru ini diterbitkan antara lain: "Building Harmony through Religious Reception in Culture: Lesson Learned from Radin Jambat Folktale of Lampung" di Analisa Journal of Social Science and Religion, Vol. 02., No. 02, 2017; "Tradisi Islam, Tradsi Arab dan Tradisi Jawa: Membaca Karya dan Pemikiran K.H. Ahmad ar-Rifai Kalisalak," di Jurnal Lektur Keagamaan, Vol. 15, No. 2, 2017; "Ideologi dalam Literatur Keagamaan pada Aktivis Dakwah Kampus dan Kajian Islam di ITB Bandung," di Jurnal SMART Studi Masyarakat, Religi dan Tradisi, Vol. 3, No. 1, 2017; "Membaca Kecenderungan Pemikiran Islam Generasi Milenial," dalam Harmoni, Jurnal Multikultur dan Multireligius, Vol. 17, No. 1, 2018; "Antara Ketaatan Beragama dan Toleransi Sosial: Membaca Pemikiran Guru Marzuki Muara di Betawi tentang Kafir (1877-1934)," di Jurnal Masyarakat dan Budaya, LIPI, Vol. 18, No. 1, 2016. Karya-karya lainnya bisa dilihat pada https:// scholar.google.com/citations?hl=en\&user=MDezWOkAAAAJ. Bisa dihubungi melalui agus.iswanto83@gmail.com dan 08170406878. 
Bisri Ruchani adalah peneliti ahli madya di Balai Litbang Agama Semarang, lahir di Kudus, 6 Juni 1956. Riwayat pendidikan: Sarjana Muda IAIN Kudus, Sarjana Lengkap IAIN Walisongo Semarang, dan saat ini sedang menyelesaikan pendidikan pascasarjana di UIN Walisongo Semarang. Publikasi karya ilmiah: Naskah keagamaan yang memuat nilai-nilai kerukunan di NTB dan Kalsel: naskah lontar Takepan Nabi Adam di Lombok: laporan penelitian, 2012. Laporan penelitian inventarisasi dan digitalisasi naskah klasik keagamaan di Madura (Kab. Sumenep dan Kab. Pamekasan), 2012 . Studi kitab tradisi Islam karya KH. Nawawi Berjan Purworejo, 2011. Kajian nilai-nilai kerukunan dalam naskah serat Purwocampur, 2011. Studi masjid Pathok Negoro Plosokuning Kab. Sleman, DIY, 2011. Nomor HP: 081542566616, Email: bisri.ruchani@gmail.com.

Moch. Lukluil Maknun, peneliti ahli muda pada Balai Litbang Agama Semarang. Lahir pada 13 Nopember 1984 di Blitar, Jawa Timur. Menamatkan pendidikan S-1 Sastra Asia Barat pada 2006 dan S-2 Kajian Timur Tengah pada 2012 di UGM. Di antara karya tulisnya: (1) "Harmoni Hindu-Muslim Berbasis Tradisi Lisan Sejarah Desa Saren Budakeling Karangasem Bali" terbit di Jurnal Fikrah Vol. 6(2), 2018; (2) "Legenda Lok Laga (Studi Lirik Lagu Musik Panting Kalsel)" terbit di Jurnal Panangkaran Vol. 1(2), 2017; (3) "Literatur Keagamaan Rohis dan Wacana Intoleransi", monograf terbitan Litbangdiklat Press Kemenag sebagai penulis pertama, 2018.

Mustolehudin adalah peneliti ahli madya pada Balai Litbang Agama Semarang. Lahir pada 25 Mei 1974 di Kebumen, Jawa 
Tengah. Pendidikan S1-nya ditempuh di IAIN Walisongo Fakultas Ushuluddin Jurusan Akidah Filsafat lulus tahun 1998. Pada tahun 2003 mendapat kesempatan tugas belajar S1 Ganda Ilmu Perpustakaan di Universitas Yarsi Jakarta dari Badan Litbang dan Diklat Kemenag RI dan lulus tahun 2007. Pada tahun 2010 meneruskan Pascasarjana IAIN Walisongo dengan konsentrasi Etika/Tasawuf dan lulus tahun 2012. Beberapa tulisan terbarunya antara lain: (1) "Dinamika Peribadatan Gereja Injili di Indonesia Pasca Konflik Tolikara (Studi Kasus di Desa Mojokerto Kecamatan Kedawung Sragen), Jurnal Dialog; (2) "Kejawen Spiritualism: The Actualization Of Moral Values In Paguyuban Suci Hati Kasampurnan In Cilacap, Central Java," terbit pada Jurnal El Harakah UIN Maulana Malik Ibrahim Volume 19 No.2, 2017 (menulis bersama Siti Muawanah); (3) "Islam, gay, and marginalization: a study on the religious behaviours of gays in Yogyakarta," terbit pada Indonesian Journal of Islam and Muslim Societies, Vol. 7, no.1 (2017), pp. 125152, doi : 10.18326/ijims.v7i1.125-152 (menulis bersama Prof. Koeswinarno); (4) "Pemikiran pendidikan K. H. Ali Maksum Krapyak Yogyakarta", terbit pada jurnal Edukasi Volume 16 No. 1, 2018 (menulis bersama Siti Muawanah). (5) "Building Harmony Through Religious Counseling (The Religious Harmony Portrait in North Mamuju)", terbit pada Jurnal Esensia Volume 19 Nomor 1 (2018) jurnal Fakultas Ushuluddin UIN Sunan Kalijaga.

Nur Laili Noviani, lahir di Semarang, 9 November 1985, merupakan peneliti yang bertugas pada Balai Penelitian dan Pengembangan Agama Semarang. Peneliti Pertama ini 
mendapatkan gelar pendidikan S1 dari Fakultas Psikologi Universitas Diponegoro, Semarang pada tahun 2007. Lima karya terakhirnya, yaitu: (1) "Challenge for the Islamic Studies Senior High School Teacher in Implementing the 2013 Curriculum in SMAN 1 Salatiga"(Analisa: Journal of Social Science and Religion Vol. 1, No. 2, December 2016); (2) "Peran Sugesti bagi Orang Kalang dalam Melestarikan Tradisi Kalang di Desa Lumansari, Kendal" (Jurnal SMaRT: Studi Masyarakat, Religi, dan Tradisi Vol. 2, No. 2, Desember 2016); (3) "Building Harmony Through Religious Counseling (The Religious Harmony Portrait in North Mamuju)" (Ditulis bersama dengan Muhammad Dachlan dan Mustolehudin dalam Jurnal Esensia Vol. 19, No. 1, April 2018); (4) "Literasi Al-Qur'an Siswa SMP di Jawa Timur: Capaian serta Partisipasi Orang Tua dan Masyarakat" (Ditulis bersama Agus Iswanto, dkk dalam Suhuf: Jurnal Pengkajian Al-Qur'an dan Budaya, Vol. 11, No.1, Juni 2018); (5) "The Map of SMA/SMK Islamic Education Teachers' Competencies in Central Java" (Ditulis bersama Umi Muzayanah, dkk terbit dalam Analisa: Journal of Social Science and Religion Vol. 3, No. 2, 2018).

Roch Aris Hidayat adalah peneliti ahli madya di Balai Litbang Agama Semarang. Lahir di Magetan, 30 Maret 1966. Dia menyelesaikan pendidikan sarjana (S1) di Fakultas Sastra Universitas Sebelas Maret Surakarta dan pascasarjana (S2) di Program Studi Ilmu Pendidikan Bahasa (Indonesia) Universitas Negeri Semarang. Beberapa karya yang diterbitkan di antaranya; (1) "Sinkretisme dalam Sastra Mistik" Jurnal Smart Balai Litbang Agama Semarang, Vol. 4, No. 1 (2018); (2) "Sejarah, Ajaran, dan Hubungan Sosial 
Paguyuban Sumarah di Yogyakarta” (Bunga Rampai, 2017); (3) "Potensi Radikalisme dalam Literatur Keagamaan Analisis Literatur Kelompok Umar Bin Khattab Magelang” (Bunga Rampai, 2016); (4) "Wacana Keislaman dalam Kitab Risalat al-Mu'awanah" (Bunga Rampai, 2015); (5) "Kontroversi Hukum Rokok dalam Kitab Irsyād Al-Ikhwān Karya Syekh Ihsan Muhammad Dahlan", Jurnal Ihya' 'Ulum Al-Din UIN Walisongo Semarang, Vol. 17. No.2 (2015).

Subkhan Ridlo adalah peneliti ahli muda di Balai Litbang Agama Semarang. Lahir di Banyumas 22 Februari 1973. Pendidikan sarjana ditempuh pada jurusan Tafsir Hadis di Fakultas Ushuluddin IAIN Walisongo Semarang yang diselesaikan pada tahun 2001. Tahun 2011 mendapatkan gelar master di UIN Syarif Hidayatullah Jakarta pada konsentrasi Filologi Agama. Sejak tahun 2003 penulis mulai mengabdi di Balai Penelitian Agama Semarang hingga sekarang. Karya yang pernah ditulis antara lain; (1) "Agama Sarkawi di Brebes; (2) "Kajian Kitab Al-Baqiyat As-Salaihat Wa Al-Aqibat Al-Khairat Wa Al-Khatimat Al-Hasanat karya Syaikh Ahmad Asrari Kedinding”; (3) “Jejak-Jejak Perjuangan KH. Bisri Syansuri Jombang"; (4) "Kajian Kitab Karya Ulama Lokal di Kota Kediri (Studi Kitab Fathu Al-Manan Karya KH. Maftuh Bastu al-Biri"; (5) "Tabyiin Al-Islam Li Murid Al-Nikah Karya Ahmad Rifa'i Kalisalak (Suntingan Teks dan Pengungkapan isi)”.

Umi Masfiah adalah peneliti ahli madya di Balai Litbang Agama Semarang. Lahir di Banyumas, 18 Oktober 1975. Pendidikan terakhirnya Pasca Sarjana (S2) Etika Islam/ 
Tasawuf UIN Walisongo Semarang. Beberapa karya yang baru terbit adalah; (1) "Pemikiran Kalam Kiai Muhammad Sami'un Purwokerto dalam Naskah Aqaid 50" dalam Jurnal Smart: Studi Masyarakat, Religi, dan Tradisi, Des 2017; (2) "Ajaran Sarengat, Tarekat, Hakekat, dan Makrifat dalam Naskah Serat Jasmaningrat" dalam Smart: Studi Masyarakat, Religi, dan Tradisi, Juli 2016; (3) "Falsafah Damai untuk Borneo (Studi terhadap Pesan Damai dalam Karya Cendekiawan Muslim Kalbar Pasca Reformasi)," dalam Smart: Studi Masyarakat, Religi, dan Tradisi Juni 2015; (4) "Nilai-Nilai Toleransi dalam Buku PAI terbitan Yudhistira, Aneka Ilmu, dan Bengawan Ilmu" dalam buku Bunga Rampai berjudul Indigeneous Pemikiran Ulama Jawa tahun 2015; (5) "Paguyuban Tulis Tanpo Papan Kasunyatan Jati Singgangsono (TTPKJS) di Yogyakarta" dalam Prosiding Eksistensi dan Ajaran Penghayat Kepercayaan di Jawa, 2017. 


\section{INDEKS}

A

Abdidalem 170, 181, 189, 193, 195, 196, 197, 198, 199, 203, 204, 205, 206, 207, 209

B

Bali iii, viii, 3, 4, 5, 6, 7, 13, 14, 15, 16, $17,18,21,22,23,25,26,28$, $31,33,34,35,37,38,39,41$, $42,43,44,45,48,51,52,54$, $55,56,57,58,59,62,63,65$, $66,67,68,69,72,73,74,75$, $76,77,78,79,81,82,83,84$, $85,86,90,91,92,93,94,95$, 96, 97, 99, 100, 101, 102, 103, 104, 106, 107, 108, 109, 110, $111,112,118,119,120,121$, $122,128,129,131,132,133$, 134, 135, 138, 155, 243, 300, $319,320,326,327,330,331$, $334,335,337,338,339,344$

Budaya $1,2,3,5,6,7,10,12,13,22$, $25,26,27,38,39,40,51,57$, $67,68,83,92,93,97,98,99$, $101,102,104,105,106,108$, $111,115,118,119,120,122$, $129,132,133,137,148,165$, 167, 168, 169, 188, 205, 208, 209, 210, 217, 218, 219, 220, 221, 222, 234, 235, 239, 240, 243, 249, 251, 255, 258, 278, 282, 283, 287, 293, 297, 298, 299, 308, 310, 311, 318, 319, $321,322,324,326,341$

Bugis $4,16,22,34,89,90,92,100$

Buleleng 5, 13, 21, 22, 24, 25, 28, 29, $31,32,33,40,44,49,50,55$, $58,59,62,63,83,100,107$,
108, 109, 135, 311, 327, 335, 340

Burdah 5, 13, 14, 15, 16, 22, 39, 40, 41, 42, 43, 44, 45, 46, 48, 49, $50,51,53,54,57,59,60,61$, $278,311,312$

$\mathrm{C}$

Code xii, 101, 105, 217, 111, 115, 246

F

Folklor 12, 13, 17, 18, 63, 98, 163, 210, 176, 177, 221, 222, 223, 228, 229, 249, 328, 329, 334, 338

G

Garebeg 170, 189, 190, 191, 192, 194, $195,209,214,215,340$

Garebeg Besar 189, 190, 192, 194

Garebeg Mulud 189, 190, 191, 192, 194

Garebeg Sawal 189, 190, 192, 194, $195,209,215,340$

Geertz 1, 18, 167, 168, 211, 255, 256, 257, 293, 294, 329, 336

$\mathrm{H}$

Halal bi halal 16, 208

Harmoni iii, 2, 17, 92, 328, 343, 344

Hermeneutik 225, 226 227, 255

Hindu 2, 4, 5, 21, 22, 23, 26, 27, 29, $30,31,32,39,41,42,43,44$, $48,49,50,52,55,56,57,58$, $59,60,62,63,74,77,78,81$, $86,88,91,93,94,99,100,101$, 
$107,108,120,121,122,127$, $128,129,130,134,138,142$, $166,189,233,326,335,341$, 344

\section{I}

Identitas xi, 1, 3, 14, 15, 17, 27, 28, $75,76,87,93,95,96,97,133$, $135,258,165,178,180,249$, 258, 265, 272, 279, 291, 331, 339

Islam iii, iv, 4, 5, 9, 15, 16, 18, 21, 22, $23,27,29,30,32,33,37,39$, 40, 43, 44, 50, 51, 52, 56, 59, $60,63,65,66,68,74,75,76$, $77,78,80,83,85,87,88,93$, $95,100,101,104,107,108$, $110,111,112,122,127,129$, $130,133,134,137,138,142$, $162,165,166,167,168,169$, 170, 182, 184, 186, 187, 188, 189, 190, 191, 192, 193, 194, 207, 208, 209, 210, 212, 213, 214, 215, 216, 226, 233, 249, 251, 259, 278, 279, 280, 281, 287, 293, 294, 295, 318, 325, $326,330,332,333,334,335$, $337,338,339,340,341,342$, $343,344,345,347$

Islamisasi 168, 169, 170, 187, 279, 294,336

\section{J}

Jawa iii, viii, 3, 4, 11, 13, 14, 17, 22, $31,32,34,52,66,77,83,84$, 92, 99, 100, 101, 103, 106, 108,
$110,134,138,156,157,165$, $166,167,168,169,170,175$, $180,184,185,186,187,188$, 189, 190, 192, 193, 194, 195, 196, 197, 199, 208, 209, 210, 212, 213, 214, 216, 240, 245, 247, 249, 250, 259, 269, 272, 279, 280, 288, 291, 293, 294, 295, 300, 318, 325, 326, 327, $328,332,333,334,335,336$, $337,339,342,343,344,346$, 348

Joharsa, Geguritan 1 5, 101, 102, 111, $112,115,117,126,131,133$, 319,320

K

Karakter iii, 8, 18, 50, 163, 212, 213, 307, 309, 310, 323, 329, 330, $332,334,335,336,337,338$

Kearifan Lokal 54, 99, 102, 133, 218 , 220, 258, 279, 311, 313, 319, 321

Kepaon 13, 66, 67, 68, 69, 72, 74, 75, $76,77,78,79,80,81,82,83$, $84,85,86,87,88,89,90,91$, $92,93,94,95,96,97,107$

Keraton 13, 14, 166, 170, 180, 181, 183, 184, 186, 189, 190, 191, 192, 193, 194, 195, 199, 200, 206, 207, 208, 209, 210, 211 , $215,317,318,326,329,340$, 341

Kerukunan 2, 15, 24, 26, 43, 54, 74, $142,217,218,219,220,224$, $225,227,246,344$ 
konflik 2, 24, 27, 81, 82, 92, 97, 185, 218

$\mathrm{L}$

Lombok iii, viii, 3, 4, 13, 14, 15, 34, $108,110,137,138,139,140$, $141,142,143,145,157,161$, $162,163,325,326,328,336$, 339,344

$\mathrm{M}$

Manuskrip 107

Mauludan Base 21, 22, 23, 24, 28, 31, $39,40,42,43,50,51,56,59$, 60,61

Merti 233, 235, 244

Milenial xii, 297, 300, 302, 322, 323, $324,326,330,334,337,343$

Muslim Bali 5, 14, 75

$\mathrm{N}$

Naskah 13, 62, 102, 104, 107, 108, $111,131,133,134,212,320$, $328,331,333,344,348$

Ngabekten 13, 14, 16, 170, 171, 180, 181, 182, 183, 184, 192, 193, 194, 195, 196, 197, 198, 199, 200, 201, 202, 203, 204, 205, 206, 207, 208, 209, 210, 212, $215,317,318,331,333,340$

$\mathrm{P}$

Pegayaman 5, 13, 15, 16, 21, 22, 23, $24,25,26,27,28,29,30,31$, $32,33,34,35,37,38,39,40$, $42,43,44,45,48,49,50,51$, $52,53,54,55,56,57,58,59$, $60,61,62,327,330$

Pekalongan 13, 14, 250, 254, 257, 258,
259, 260, 261, 262, 263, 264, 265, 267, 268, 269, 270, 271, 273, 274, 275, 276, 277, 279, 280, 286, 287, 288, 292, 293, 294, 313, 327, 328, 330

Pendidikan Karakter iii, 7, 9, 18, 50, 212, 213, 299, 309, 310, 323, $329,330,332,334,335,336$, 337,338

$\mathrm{R}$

Religi xi, 6, 16, 21, 39, 50, 54, 56, 65, $88,93,134,137,190,251,308$, $313,335,343,346,348$

Ritus 256, 298

Rudat $65,66,67,68,69,72,74,75$, $76,77,78,79,80,81,82,83$, $84,85,86,87,88,89,90,91$, 92, 93, 94, 95, 96, 97, 98, 326, 330

S

Sejarah 2, 3, 11, 14, 17, 24, 31, 32, 33, 57, 59, 67, 74, 79, 99, 104, 138, 169, 176, 179, 191, 249, 251, 261, 262, 264, 267, 281, 286, 287, 292, 301, 313

Seka Burdah 40, 41, 42, 43, 44, 42, 45, $49,50,51,54,61$

Sekaten 190, 191, 215, 340

Selametan 195

Semiotika 101, 105, 111, 119, 229

Seni $4,5,13,14,15,65,68,78,79$, $85,86,87,93,95,96,251,254$, 259, 261, 267, 274, 293, 313, 325,327

Sintren 13, 14, 15, 250, 251, 252, 254, 257, 258, 259, 260, 261, 262, 263, 264, 265, 266, 267, 268, 269, 270, 271, 272, 273, 274, 
$275,276,277,278,279,280$, $281,282,283,284,285,286$, 287, 288, 289, 290, 291, 292, 293, 294, 295, 313, 317, 325, $330,338,342$

Sorong Serah Aji Krama 13, 14, 139, $142,143,145,146,152,156$, $157,161,163,342$

Subak $35,38,39,59,60$

$\mathrm{T}$

Teknologi informasi 183, 299, 305, 314,315

Toleransi $16,21,22,24,26,50,54,57$, $59,60,81,83,91,97,224,312$

Tradisi lisan vii, viii, 2, 3, 5, 6, 7, 8, $10,11,12,13,14,15,25,26$, $66,97,140,142,161,170,171$, $172,179,180,181,182,193$, 219, 220, 221, 226, 227, 228, 230, 245, 246, 249, 257, 299, 312,317

Tradisional 2, 10, 12, 75, 103, 177, $178,179,193,207,220,221$, 222, 223, 226, 229, 254, 261, $268,270,298,316,323,336$

V

Vansina, Jan 215

W

Walisongo 251

Woodward, Mark R 215, 341

Y

Yogyakarta 2, viii, 14, 17, 18, 63, 72, 134, 162, 163, 166, 170, 180, $181,183,184,185,186,187$, 188, 189, 190, 191, 192, 193, 194, 195, 199, 200, 206, 207,
208, 209, 210, 211, 212, 213, 214, 215, 216, 220, 230, 231, 233, 238, 239, 245, 246, 247, 293, 294, 295, 300, 317, 325, $326,327,328,329,331,332$, $333,334,335,336,337,338$, $339,340,341,342,343,345$, 347,348 


\section{TRADISI LISAN, PENDIDIKAN KARAKTER, DAN HARMONI UMAT BERAGAMA DI ERA 4.0 PENGALAMAN BALI, LOMBOK, DAN JAWA}

Buku ini hadir atas inisiatif para peneliti bidang lektur, khazanah keagamaan, dan manajemen organisasi di Balai Litbang Agama Semarang. Salah satu obyek di bidang khazanah keagamaan adalah mengenai tradisi lisan (oral tradition). Buku ini adalah suatu upaya mengkontekstualisasikan beragam tradisi lisan yang ada di berbagai masyarakat yang diteliti ke dalam situasi dan kebutuhan saat ini. Hadirnya buku ini bukan merupakan suatu "langkah mundur" yang terjebak pada "romantisme" belaka karena terlalu mengunggulkan tradisi. Namun, buku ini berupaya mencari sisi postitif dari berbagai tradisi lisan yang masih hidup dan penting untuk menjadi sumber penguat pendidikan karakter, dan modal sosial-kultural dalam membangun harmoni antarumat beragama.

Ada tujuh tulisan yang masing-masing menyajikan tradisi lisan yang berbeda-beda di berbagai daerah. Tujuh tulisan tersebut diantarkan oleh satu tulisan prolog, dan diakhiri dengan epilog yang mencoba menawarkan bagaimana tindak lanjut dari beragam tulisan hasil penelitian tentang tradisi lisan dalam buku ini. Tidak semua tulisan adalah hasil penelitian terbaru, beberapa tulisan adalah hasil penelitian dua tahun ke belakang. Karena masih kontekstualnya pembahasan, maka tulisan tersebut tetap dimasukan dalam buku bunga rampai ini. Tulisan-tulisan menyajikan tradisi lisan dari berbagai daerah yang masuk ke dalam wilayah kerja Balai Litbang Agama Semarang: Jawa Tengah, Yogyakarta, Bali, dan Lombok. Hal yang menarik adalah ketiga wilayah tersebut memiliki titik persinggungan dalam hal kebudayaan.
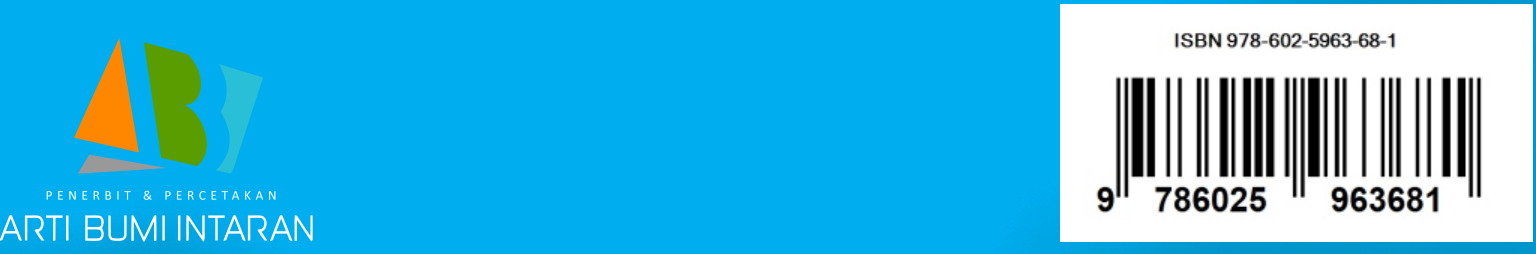